\title{
Héroes para la nación. La edificación de la tradición septembrina mexicana
}

\section{National Heroes. The Construction of Mexico's September Traditions}

\author{
Mariana Terán Fuentes \\ Universidad Autónoma de Zacatecas \\ marianateranuaz@gmail.com \\ Mónica Pérez Navarro \\ monicaprz@gmail.com \\ DOI: I0.2490I/rehs.v40iI57.347
}

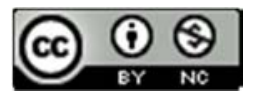

Héroes para la nación. La edificación de la tradición septembrina mexicana por Mariana Terán Fuentes y Mónica Pérez Navarro se distribuye bajo una Licencia Creative Commons Atribución-NoComercial 4.0 Internacional.

Fecha de recepción: 4 de septiembre de 2017

Fecha de aprobación: 2I de noviembre de 2017

\section{RESUMEN:}

El propósito del artículo es analizar la construcción de la idea de nación a partir del uso político de la memoria histórica cultivada por rituales, sermones, oraciones cívicas pronunciados entre I82I y I 829. En esos años se observa un interés por definir quiénes deben ser considerados padres de la patria, héroes nacionales y fiestas para conmemorar el nacimiento de México como nación independiente. Interesa, en particular, la cuestión de la formación de una nueva mitología basada en símbolos que fueron utilizados en su calidad de fundantes: los padres de la patria y la virgen de Guadalupe, símbolos que permitieron potenciar una idea de nación de largo aliento y una historiografía de corte nacionalista.

Palabras clave:

Nación, memoria, retórica, identidad, homogeneidad. 


\section{ABSTRACT:}

In this research project, we set out to analyze the construction of the idea of a nation based on the political use of historical memory that was nurtured from I82I to I829 through rituals, readings and civic discourses. That period was characterized, among many other elements, by a growing interest in defining who should be considered the nation's founding fathers and national heroes, complemented by celebrations held to commemorate Mexico's birth as an independent country. Particularly interesting in this context was the construction of a new mythology based on a series of symbols that were chosen because of their foundational characteristics; especially the founding fathers and the Virgin of Guadalupe, symbols that served to promote the idea of a long-established nation with a nationalist historiography.

Keywords:

Nation, memory, rhetoric, identity, homogeneity.

¿Qué nación: española, americana, mexicana?

El Diccionario de autoridades consigna el sentido del vocablo nación como lugar de nacimiento, "el acto de nacer. En este sentido se usa en el modo de hablar de nación, en lugar de nacimiento"; como "colección de habitadores, en alguna provincia, país y reino", o para designar "cualquier extranjero". En las crónicas religiosas el vocablo era empleado para designar comunidades identificadas principalmente por su criterio étnico, "naciones chichimecas" o "naciones de indios bárbaros"; en la oratoria sagrada novohispana, en particular, la dedicada a la virgen de Guadalupe, la nación es referida a la americana, la elegida por María para su aparición y portentoso milagro "por ser maravilla no concedida a otra nación, Non fecit taliter omni nationi [...] ¿Qué reconocemos en esta bellísima imagen de María? Una hermosa modesta indiana. La túnica, el manto, el traje, es todo de su nación [...] su imagen indiana, por eso se nos propone tan nuestra”.

María Moliner alude a otros elementos que relacionan a una comunidad que ocupa un territorio: raza, historia, gobierno, usos y la existencia de un mismo idioma. ${ }^{4}$ Nación también se remitía a la conciencia de grupo de "formar nación" gracias a elementos de comunidad como raza, religión y costumbres. Su semántica durante el siglo XVIII se asociaba a los vocablos patria y tierra como lugar de origen, de nacimiento y a la pertenencia a un determinado grupo social. 5 Fue hasta el siglo XIX cuando el vocablo adquirió sus referencias jurídica y política en tanto conformadora de unidad, uniformidad y territorialidad. Como lo ha reflexionado Eric Hobsbawn, el concepto en tanto abarca la acepción política de nación es muy joven desde el punto de vista histórico, lo caracteriza la connotación de moderna. - Por su naturaleza política e ideológica, la connotación moderna del concepto nación, además, tuvo y tiene consecuencias de enorme trascendencia en nuestra concepción de la historia. Como apunta Mauricio Tenorio: "la historia de las Américas no es otra cosa que el conjunto de historias nacionales. Todas estas historias son empírica e intelectualmente hijas del sigo XIX". 
La idea de patria designaba el sentido territorial, material y locatario de lugar de nacimiento

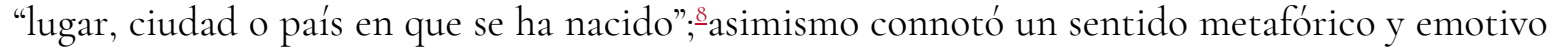
como la pertenencia a un mundo social, jurídico y político mayor, en tanto "nación propia nuestra con la suma de cosas materiales e inmateriales, pasadas, presentes y futuras que cautivan la amorosa adhesión de los patriotas". ${ }^{2}$ La idea de patria monárquica española tuvo ese sentido de pertenencia a una unidad mayor donde se encontraba, desde luego, la referencia al lugar de nacimiento y la permanencia de los lazos de lealtad a la patria, al rey, a la religión. Para Benito Jerónimo Feijoo, siguiendo al prelado inglés Juan Sarisberiense, el cuerpo político de la república era como el cuerpo humano identificado por la religión católica como el alma, el príncipe la cabeza, el consejo el corazón, los virreyes los ojos, los militares los brazos, los administradores el estómago y los intestinos, y los labradores los pies. Los pies donde descansa el cultivo de la tierra, debían estar bajo la permanente vigilancia y protección de la cabeza "porque sustentan y dan movimiento a todo el cuerpo"; si los pies están cansados, España sufre de gota, "gotosa España". $\frac{10}{}$

La coyuntura que evidenció la crisis dinástica, política y de soberanía del imperio español fue a propósito de la ocupación militar de Napoleón Bonaparte en la península en i807 y los acontecimientos políticos que se desataron vertiginosamente. En I8o8 se aglutinó un conjunto de problemas financieros, enfrentamientos bélicos entre España con otras potencias europeas y ocupación militar de Napoleón Bonaparte en la península ibérica. Ese año fue crucial porque la presencia francesa implicó un profundo trastocamiento al orden político, jurídico y social de la monarquía española en su conjunto. Frente a los acontecimientos sucedidos en Bayona donde el rey de la monarquía española había cedido la Corona a Napoleón y éste a su hermano José, las respuestas comunes en ambos hemisferios reflejaron el rechazo a la figura napoleónica considerada como usurpadora.

En cabildos y corporaciones retomaron los libros de la tradición legal castellana, las Siete Partidas, o los escritos de Covarrubias de quien citaban la tesis de la legitimidad en el proceso de sucesión: "la sucesión se ha adoptado en España por el consentimiento general del pueblo. Luego, sin su anuencia y voluntad, no puede el soberano mismo constituir otro rey sobre nosotros que no provenga de la dinastía recibida por la nación"; la nación estaba circunscrita a la tradición pactista entre el monarca y sus vasallos; los ayuntamientos se dieron a la tarea de analizar la ilegitimidad del intruso que no provenía de la "dinastía recibida por la nación", ni mucho menos de la abdicación del rey a la Corona. Esas tesis se discutieron en los ayuntamientos y después en las juntas provinciales. Los movimientos de las guerras de insurgencias en la América española y el establecimiento de las Cortes Generales y Extraordinarias en la isla de León con la presencia de diputados españoles y americanos representaron uno de sus más elocuentes impactos.

Todo esto se dio en un par de años. Manuel Chust le ha llamado a i8o8-ı8ıo el bienio trascendental; $\stackrel{\amalg}{ }$ François-Xavier Guerra los analiza como los dos años cruciales, "época clave de las revoluciones hispánicas, tanto en el tránsito hacia la Modernidad, como en la gestación de la Independencia"; ${ }^{12}$ Jaime E. Rodríguez lo ve como la gran revolución en Hispanoamérica que tuvo dos vías: la armada, con las insurgencias, y la parlamentaria, con las Cortes; un levantamiento 
popular que devino en una revolución política: la revolución hispánica, para Virginia Guedea. ${ }^{13}$ Finalmente, Claudia Guarisco ha subrayado la necesidad de destacar que de este periodo tan exigido de reflexión sobre la soberanía, la naturaleza misma de las entidades políticas y las relaciones sociales, impactó de modo irreversible las formas de la participación de los sujetos nacionales redefiniendo los espacios políticos y, muy importante, los elementos de referencia de las nuevas identidades consecuentes de dicha redefinición..$^{ \pm 4}$

Las muestras de lealtad a la patria, al rey y a la religión expresaron una inusitada respuesta patriótica con ceremonias de juramento al monarca, numerosas representaciones de distintas corporaciones como ayuntamientos y repúblicas de indios y donativos y préstamos a la Corona. En algunas de las capitales novohispanas se formaron compañías así llamadas de fernandinos "iVasallos de Fernando, dispuestos a morir por la religión, por la patria y por su rey!" Otros cabildos publicaron bandos solemnes para que sus habitantes portaran en el sombrero una cucarda roja, símbolo de lealtad al monarca. Grupos de artesanos en las minas de Sombrerete, en la intendencia zacatecana, pidieron armas y que los adiestraran para defender a Fernando VII. El cautiverio de la familia real representó un momento de extraordinaria participación de las corporaciones de ciudades, villas y pueblos por defender ese cuerpo político llamado patria. ${ }^{\underline{\underline{6}}}$

A propósito de las instrucciones y poderes que se solicitaron a las intendencias y subdelegaciones para la representación del diputado Miguel de Lardizábal ante la Junta Central en i8o9, es muy ilustrativo el documento que elaboró el cabildo zacatecano al pedir "que se restituya a la nación congregada en Cortes, el poder legislativo", como el único mecanismo para "lograr el equilibrio perfecto", era menester, como ya lo había redactado con amplitud Francisco Martínez Marina, acomodar "el espíritu de las antiguas leyes a las actuales circunstancias del día", ${ }^{17}$ con el propósito de salvaguardar a la patria. Ese poder fue redactado por los miembros del ayuntamiento zacatecano en I809; fue una prueba significativa de lo que algunas corporaciones políticas estaban discutiendo: la necesidad de un nuevo cuerpo legislativo capaz de conformar y defender a la nación. En tal sentido, nación en I8og se vinculaba ahora, en situación de crisis política y dinástica, a la urgencia de convertir las cortes en legislativas.

Para el caso de la Nueva España, el mes de septiembre de i8 Io contiene dos sucesos políticos extraordinarios: el día i6 con el llamado del cura Miguel Hidalgo a levantarse en armas desde la parroquia de Dolores - conocido como el Grito de Dolores-, y el día 24 con la instalación de los diputados en las Cortes Generales y Extraordinarias en la isla de León. Mientras que Hidalgo en la madrugada del i6 de septiembre llamó a los artesanos e interpeló a Ignacio Allende con la sentencia "ahora mismo damos la voz de libertad", tomó la imagen de la virgen de Guadalupe y desde un balcón levantó la voz “iViva nuestra Señora de Guadalupe! ¡Viva la independencia! Y contestamos ¡Viva! Y no faltó quien añadiera ¡Y mueran los gachupines!”, $\stackrel{18}{\text { a }}$ las 9 de la mañana del 24 de septiembre, desde las Casas Consistoriales en la Real Isla de León en España, se dio inicio a la ceremonia de instalación de los diputados primero con su trayecto a la iglesia parroquial para escuchar la misa del Espíritu Santo, al término juraron la religión católica, la defensa de la integridad de la nación española, la conservación del soberano y sus dominios, guardar y mejorar, en su caso, las leyes por el bien de la nación. Después del ritual cívico religioso, pasaron a ocupar sus asientos en el recinto legislativo para declarar la nación 
congregada en Cortes, la nulidad de la abdicación de la Corona, el rechazo a cualquier imposición de la soberanía de otra nación extranjera, la separación de poderes y el papel del ejercicio legislativo en las Cortes "en toda su extensión". 무

Un año que no deja de ser emblemático por la condición política en que los letrados y representantes de los distintos reinos de la monarquía discutían la posibilidad de formar una nación fue i8ro-i8Ir. Desde España se proclamó la Constitución política de la monarquía donde se reconocía como comunidad política nacional la reunión de los hemisferios americano y español, siguiendo la declaratoria de la Junta Central; se trató de una constitución elaborada, discutida, argumentada y firmada por diputados españoles y americanos. A diferencia de lo que sostiene Hobsbawm que fue hasta I884 cuando el término de gobierno se asocia directamente a nación,, 20 el ejemplo gaditano expresa que nación española es reunión de territorios, leyes comunes y gobierno compartido en sus tres niveles de representación: monárquico, provincial y municipal y en el ejercicio de la división de poderes. El liberalismo hispano se mostraba al mundo como el código sagrado que representaba en materia política y jurídica un paradigma al lado de importantes documentos de carácter revolucionario como la Declaración de los Derechos del Hombre y del Ciudadano (I789) y la Constitución Política de Estados Unidos de Norteamérica (1787).

A diferencia de Francia donde el rey vio su fin en la guillotina, la experiencia constitucional hispana colocaba al rey en su trono, pero regido por una constitución de nación. He aquí el nuevo sujeto en Hispanoamérica: la nación española gobernada por una constitución redactada por diputados americanos y peninsulares. .I $^{-}$Aquel sentido locatario de nación como "lugar de nacimiento" se vio profundamente revolucionado al concebirla como la unidad política mayor donde tenían los mismos derechos de representación tanto la España peninsular como la América ultramarina. La nación se debió, por tanto, a la confluencia de distintos factores que le dieron origen. No es un término atemporal o ahistórico, ni una realidad inmanente, sino una realidad histórica $; \frac{22}{y}$ precisamente en su carácter histórico, desde las Cortes Generales y Extraordinarias instaladas en el puerto de Cádiz, el primer título de la Constitución Política de la Monarquía Española, definía a la nación española como la reunión de todos los españoles de ambos hemisferios; libre e independiente; alejada de cualquier indicio de patrimonialismo, donde la soberanía residía esencialmente en ella y por eso contaba con el derecho de establecer sus propias leyes y con la obligación moral de proteger "por leyes sabias y justas" el conjunto de derechos de los individuos que la componen. Esa nación española, regida por una Constitución, venía a representar el principal medio de defensa en contexto de crisis dinástica donde el rey estaba en cautiverio y el usurpador seguía demostrando no sólo su avance y desafío militar, sino su derecho de imponer un orden constitucional, como claramente lo reflexiona José María Portillo Valdés:

Era en ese escenario donde se descubría la soberanía como un derecho nacional y no como mero principio filosófico. Nación era así sociedad dotada de un derecho radical, un derecho inajenable, un derecho anterior a todos los demás derechos. La monarquía no podía ser otra cosa que expresión de esa soberanía social, en primer

Relaciones Estudios de Historia y Sociedad, vol. XL, núm I57, 2019 
lugar para ser compatible como forma de gobierno con la libertad y, en segundo término, para poder ella misma afianzarse. ${ }^{23}$

En su parte final, la Constitución Política de la Monarquía Española de i8 I2 decretaba que aquel documento debía divulgarse entre niños y jóvenes de todo el orbe hispano, ser enseñado para cultivar el espíritu público con las obligaciones y derechos del ciudadano de la nación. Cartillas y catecismos políticos se elaboraron para repetir una y otra vez qué era nación, en qué consistía la soberanía nacional, cuál era el papel de las Cortes en la monarquía. El Catecismo político arreglado a la Constitución de la Monarquía española, publicado el mismo año de su promulgación, formulaba la pregunta “¿Tiene dueño esta nación?” La respuesta era tomada de los artículos 2 y 3 de la Constitución: "No, porque siendo libre e independiente no es ni puede ser el patrimonio de ninguna familia ni persona; además de que en ella reside esencialmente la soberanía y por lo mismo le pertenece el derecho de establecer sus leyes fundamentales". ${ }^{24}$ Dorothy Tanck de Estrada refiere la Cartilla o catecismo del ciudadano constitucional con la exposición del Credo del ciudadano: "creer de todo corazón en la Constitución, pues que ella nos ha de redimir" y, entre los diez mandamientos, "Amar a Dios y después a la Constitución sobre todas las cosas". ${ }^{25}$ Los ayuntamientos organizaron ceremonias para reconocer al nuevo código, el cabildo de Cádiz con un "Himno Patriótico" compuesto por Juan Antonio Carazo de la Peña y música de Federico Moretti: "/;Oh padres de la patria!//Que ya nos habéis dado/ /el código sagrado/ / de nuestra libertad/".

Frente a esa compleja construcción de nación española elaborada por los legisladores en Cádiz, otras formas de fraguar la nación se dieron de manera paralela; en el caso de la Nueva España, el propósito del cura Miguel Hidalgo era la defensa de la patria frente al mal gobierno de los "gachupines" que pretendían entregarla a los franceses; en su primera proclama el líder hablaba de sagrada redención, causa santísima, nuestros derechos dados por Dios y por la naturaleza. ${ }^{27}$ Fue elegido capitán general y protector de la nación "estoy legítimamente autorizado por mi nación para los proyectos benéficos que me han parecido necesarios a su favor. Éstos son igualmente útiles y favorables a los americanos y a los europeos que se han hecho ánimo de residir en ese reino; y se reducen a proclamar la independencia y libertad de la nación". $\underline{28}$ Luis Castillo Ledón y Carlos Herrejón reconstruyeron con lujo de detalle la vida de Hidalgo para apreciarlo en todas sus dimensiones: su trayectoria educativa, sus lazos familiares y sociales, sus lecturas y momentos de esparcimiento, las difíciles circunstancias que le tocó vivir en las parroquias de Colima y San Felipe, el levantamiento y su participación en la guerra. Ambos historiadores dedicaron años de trabajo para entender el indiscutible liderazgo de Hidalgo en el inicio de la guerra de insurgencia. Castillo Ledón lo llamó Hidalgo, el héroe; Herrejón, "ícono de nuestro nacionalismo". 29

El grupo que continuó la insurgencia, encabezado por José María Morelos, sintetizó el nuevo sentido político de nación, la americana, como una entidad y comunidad diferenciada de aquel lazo que la unía con la Corona española. La nación americana se conformaba por un territorio, por órganos de gobierno autónomos, por un ideario que aclaraba por qué se encontraban en situación de guerra, por el calibre de sus propósitos y el diseño de un nuevo pacto que definiera sus límites y alcances. 
Los escritos que circularon en los periódicos del Ilustrador Americano y el Ilustrador Nacional, así como los documentos elaborados por José María Cos, el Plan de paz y guerra (I8I2), los Elementos de la Constitución (I8I2) de Ignacio López Rayón y los Sentimientos de la nación(I8I3) de José María Morelos, fueron fraguando la idea de una nación americana, una comunidad política residente en América, amparada por la virgen de Guadalupe, separada de España y de cualquier otra que pretendiera imponer su dominio. En el Plan de paz y guerra se hacía referencia -como en la Constitución de Cádiz- a la soberanía nacional, pero se ponía énfasis en el principio de igualdad entre España y América, el rechazo a cualquier tipo de subordinación entre ambas, el derecho que tenía América (así como lo demostró tener el mundo hispano) de constituir una Corte. La posición del autor del Plan frente a las Cortes de Cádiz es que aquellos diputados no eran representantes de los verdaderos intereses americanos, ${ }^{30}$ nación era comunidad política que representa y defiende los intereses de sus territorios.

En los Elementos de la Constitución de López Rayón, se declaraba en primer lugar, la adhesión a la religión católica; en segundo término, la libertad e independencia de América con respecto a cualquier otra nación; y en tercer lugar, el tema de la soberanía establecida a través de una relación tripartita entre el pueblo, de quien dimana, el rey Fernando VII en quien reside y el Supremo Consejo Nacional Americano, que la ejerce. ${ }^{31}$ En su artículo 33 se establecieron como días para solemnizarse el 16 de septiembre por "nuestra feliz independencia", el 29 de septiembre y 3 I de julio por corresponder a los días de nacimiento de Hidalgo y Allende. El i2 de diciembre se reservó para honrar a la virgen de Guadalupe, lo que significó por una parte continuar la tradición festiva novohispana a Guadalupe, al tiempo que se reforzó su semántica asociada a la nación americana. Estos días serían solemnizados "como los más augustos de nuestra nación". ${ }^{22}$ Con los Elementos de la Constitución fechados el 30 de abril de i8r2 se dio inicio a la prescripción de conmemorar a los que se reconocieron como los iniciadores de la independencia en septiembre de i8ro, cuestión significativa que continuará Morelos.

A partir de la declaratoria de solemnizar los días i6 de septiembre de cada año en los Elementos de la Constitución, se dio inicio a su ritualización el 29 septiembre de i8 2 con la ceremonia que encabezó el clérigo Francisco Lorenzo de Velasco desde Huichapan; se trata del primer panegírico dedicado a Hidalgo, impreso en Tlalpujahua. De Velasco era hijo de un realista y causó revuelo el hecho de que se hubiera incorporado a las filas insurgentes, más aún que tomara el púlpito para aclamar las hazañas del líder insurgente. Según la cuidadosa investigación de Carlos Herrejón, el autor de la pieza hizo una analogía entre San Miguel e Hidalgo, a la usanza de la hermenéutica analógica del sermón novohispano: "ambos lucharon contra el espíritu de soberbia arrogante y contra el sórdido interés: el arcángel contra la soberbia luciferina, el mexicano contra la soberbia peninsular". 33

En otras regiones del virreinato también se propiciaron los festejos del inicio de la guerra; en Zacatecas un expediente judicial fechado en noviembre de i8II dio cuenta de la participación de los religiosos del Hospital de San Juan de Dios, con la realización de honras fúnebres a los caídos en la batalla de Puente de Calderón. Al interior de las instalaciones del hospital, los hermanos dedicaron un día para recordar el alma del prior del convento fray N. Salas; uno de los frailes, fray Miguel Acuña (acusado por infidencia), fue el encargado de las honras fúnebres, 
invitó a otros religiosos de otras órdenes y pidió i2 pesos de limosna. Colocaron una pira funeraria donde "estaban las insignias de la rebelión de aquel feliz desdichado: un bastón, un espadín y un sombrero de tres picos. Todo esto se hallaba colocado a la cabeza de la tumba y a sus pies una capilla chica del santo hábito de Nuestro Padre San Juan de Dios. Todos secularizados y con sus insignias de coroneles". ${ }^{34}$ Una vez concluida la ceremonia, se mandaron repicar las campañas.

En los Sentimientos de la nación, José María Morelos definió una posición más radical a través de la declaración de la libertad e independencia de América frente a España, con la concepción de una soberanía "dimana [da] inmediatamente del pueblo" 35 depositada de manera exclusiva en el Supremo Congreso Nacional Americano, con el rechazo absoluto del poder tiránico reconocido en la presencia española. Con estos planteamientos últimos, se diferenciaba de lo expuesto por José María Cos, Ignacio López Rayón y de los líderes de la primera etapa del movimiento insurgente. Para el líder de Chilpancingo, dos eran los días del año que simbolizaban a la nueva nación americana: el i2 de diciembre dedicado a la advocación guadalupana "patrona de nuestra libertad [...] encargando a todos los pueblos la devoción mensual", y el i6 de septiembre, día del aniversario "en que se levantó la voz de la independencia y nuestra santa libertad comenzó, pues en ese día fue en el que se desplegaron los labios de la Nación para reclamar sus derechos con espada en mano para ser oída; recordando siempre el mérito del grande héroe, el Señor Don Miguel Hidalgo y su compañero Don Ignacio Allende". ${ }^{6}$ Desde el cuartel universal en Tlacosautitlán, Morelos advertía a los europeos: "ya no os canséis en inventar gobiernitos. La América es libre, aunque os pese, y vosotros podéis serlo si conducidos a vuestro suelo hacéis el ánimo, como ella, de defender la corta parte del ángulo peninsular que por fortuna os haya dejado José Bonaparte". ${ }^{37}$ Como sostiene Carlos Herrejón, "la insurgencia inauguró la celebración ritual de sus propios inicios, creándose así una conciencia de origen que se renovaba periódicamente, y así se hizo de I8I2 a I8I7 en los lugares donde dominaba la insurgencia". ${ }^{8}$

Por su parte, en el recinto legislativo de Cádiz, veían aquellos diputados la urgencia de incitar el patriotismo -expresado como la defensa de la patria-para enfrentar a su opresor, con la consigna de que los predicadores desde los púlpitos anunciaran el peligro de ser gobernados por Bonaparte. El diputado José Guridi y Alcocer separó la lealtad al rey y la lealtad a la nación: "este amor al príncipe no les separó del amor a la nación [...] jamás los americanos obedecerán a Fernando mientras vean que él es el medio de que se sirve para sus maquinaciones el mayor de los tiranos". ${ }^{39}$ El destino del rey no es necesariamente el de la nación.

Las guerras en América fueron consideradas por los diputados en las Cortes como acto de traición y flagelo a la patria, en especial, la guerra de insurgencia en el virreinato de la Nueva España. Las conmociones son un mal, una enfermedad incapaz de resolver nada. La única solución es constituir la nación. La nación no podía ser resultado de una conmoción. El diputado Gordoa y Barrios, por la provincia de Zacatecas, sostuvo en el recinto legislativo de Cádiz que la nación era resultado de un pacto donde sus vecinos se sujetan a la autoridad "por un acto de asociación política y civil; y si bien el ejercicio de ella pertenece a aquel o aquellos en cuyas manos se ha depositado el gobierno, según se ha constituido en cada nación, el derecho de todos sobre cada miembro, pertenece esencialmente al cuerpo político del Estado". ${ }^{\circ 0}$ 
Unos abogaban por la nación española que incluía el hemisferio de América, otros por la nación americana que anunciaba su separación con España. En ambas experiencias revolucionarias, la nación se superponía como una realidad omnipresente. Francisco Martínez Marina, al estudiar la tradición de las Cortes medievales, advertía en I807 "el príncipe pertenece a la nación y no la nación al príncipe; los reyes son hechos para los pueblos y no a la inversa". " Para el autor de la Teoría de las Cortes la misma existencia de la nación se debe a la tradición pactista; el pacto, "tan antiguo como el mundo".

Era ı8ı2, año en que se manifestaron ambas ideas de nación en documentos que pasaron a la historia por su impacto en el desarrollo político y jurídico del mundo hispanoamericano. Mientras que la carta gaditana buscaba recomponer la forma de gobierno monárquica a partir del tránsito de la soberanía real a la soberanía nacional, los escritos de los insurgentes, como los citados arriba, tendieron a que aquel Atlántico que antes unía, terminara por separar los territorios de América y España como preludio de la nación americana.

El presente ensayo sugiere una serie de reflexiones sobre la construcción de la identidad nacional a partir de la formación de la memoria histórica en la tradición cívica republicana en México. Desde las primeras oraciones cívicas conmemorativas del i6 de septiembre, la nación se constituyó en sujeto articulador para dar forma, cohesión y legitimidad; la memoria histórica basada en la mitología del héroe fue uno de sus vectores al pretender configurar la homogeneidad que tendiera a enfocar los rasgos comunes e integrara las diferencias culturales y sociales en un todo mayor. ${ }^{22}$

Lenguajes políticos, celebraciones rituales y elites gobernantes son elementos distintivos de esta tarea. Los primeros festejos septembrinos desde 1825 se llevaron a efecto gracias a la participación de asociaciones como sociedades patrióticas, juntas cívicas e institutos literarios a instancias de los poderes ejecutivo y legislativo. Cada I6 de septiembre -día en que se recordaba en México el inicio de la guerra de insurgencia de i8ıo con el Grito de Dolores- se daban cita en las casas del Estado gobernantes, legisladores, catedráticos, abogados, escritores, oradores, magistrados y funcionarios de las diferentes instituciones públicas para escuchar las "grandes verdades" pronunciadas desde la tribuna. Discurso, etiqueta, ceremonia y elite gobernante confluyeron para dar cuerpo a una relación simbólica conveniente entre poder y legitimidad que hizo del uso político de la memoria histórica un eje no sólo para armar la nación, sino para justificar su lugar en la nueva forma de gobierno. Se trató de un ejercicio para editar la memoria, ordenarla, periodizar la historia, enfatizar pasajes, oscurecer otros, iluminar actos heroicos, describir el emblemático septiembre de i8 Io con sus líderes, sus seguidores, su idealización y lo que significó para la nueva nación mexicana. Finalmente, esta definición del perfil de la identidad nacional supuso la "administración de la diferencia", ${ }^{43}$ la constitución de un perfil también étnico y racial que calaría bien hondo en la historiografía, la retórica y la cultura política nacionalista mexicana. 


\section{El recurso del héroe como instrumento de legitimación}

El Congreso Mexicano Constituyente, entre 1822 y I824, discutió quiénes deberían ser considerados beneméritos y héroes de la patria, qué días debían de dar forma al calendario cívico para rememorar los más importantes acontecimientos que darían lugar a la nueva nación, primero como monarquía constitucional y después como república federal.

Los diputados asentaron en actas que la consumación de la independencia en i82i debía ser considerada como un evento extraordinario para ser propagado a los cuatro vientos para que todas las naciones del orbe reconocieran a la nación mexicana. El diputado Martínez de los Ríos recordó en aquel congreso la importancia de haber "proclamado solemnemente la independencia de esta Corte, cuyo suceso llegará a noticia de todas las naciones, y se perpetuará en las historias, porque está consignado en los papeles públicos y en las medallas que se batieron". ${ }^{44}$ Acordaron la elaboración de las monedas para la coronación del primer emperador donde debía quedar impresa la imagen del Moisés Mexicano, pero indicando que se trataba de un emperador constitucional: "que en las monedas de cobre se ponga una inicial que indique ser constitucional el emperador". 4 A petición del diputado Argándar de considerar al i6 de septiembre como día de fiesta nacional por ser el que dio inicio con la emancipación, los argumentos en contra incidieron en que el inicio del movimiento con el cura Hidalgo a la cabeza había dividido a la sociedad, sin embargo se aceptó la proposición y el I ${ }^{\circ}$ de marzo de i8z2 se publicó el decreto de festividades nacionales "para perpetuar los grandes acontecimientos": 24 de febrero la proclamación del Plan de Iguala, el 2 de marzo en que el ejército trigarante lo juró, el i6 de septiembre primer grito de libertad y el 27 de septiembre la ocupación del ejército en la capital del imperio, "celebrándose con salvas de artillería y misa de gracias, a la cual deberá asistir la regencia con las demás autoridades, vistiéndose la corte de gala, y usando del ceremonial de las felicitaciones, lo que se hará extensivo a todos los lugares del imperio". ${ }^{46} \mathrm{El}$ decreto publicado el i6 de agosto de i 822 establecía además de los días anteriores y los de tabla, el i2 de diciembre "el más grande para esta América, por la maravillosa aparición de María Santísima de Guadalupe". Se aclaraba que se debía cambiar la manera de nominar el tiempo anterior: de la época de conquista, a la de "dominación de los españoles en este imperio". Era el tiempo de Iturbide y más interesó promover su figura sellada en la historia como consumador que el i6 de septiembre por lo que el decreto del 29 de agosto de i822 estableció que se celebraría la entrada del ejército trigarante a la Ciudad de México como día de fiesta nacional. ${ }^{47}$

Quedaron atrás rituales y símbolos que tuvieran relación con la "oprobiosa presencia española", como la ceremonia del besamanos "y todos aquellos rendimientos serviles establecidos por los monarcas absolutos con ofensa de la dignidad del hombre libre" 18 que recordaran la "esclavitud" de los tres siglos pasados. En lugar del besamanos, los diputados mexicanos propusieron cambiar a "día de Corte o felicitación"; ${ }^{49}$ aquella práctica del besamanos ahora era concebida como propia de la monarquía española, pero un pueblo libre -sostenían- debía crear su propio ritual concibiendo a los hombres que lo integraban en una nueva condición; el besamanos implicaba adoración, y sólo puede ser objeto de tal reverencia Dios, y no ningún hombre, por monarca que sea. El diputado Terán puntualizaba: 
Yo quisiera que abandonando este rumbo y desprendiéndose la comisión del espíritu de rutina, de que tanto adolecemos, consultara a las fuentes de la filosofía, de la moral, al estado de la civilización, y sobre todo, a las inclinaciones de nuestro pueblo; pues si éste propende a la humillación en que se le ha tenido, y prácticas algo serviles, al congreso toca rectificarlas por medio de sus instituciones, así como también infundirle usos decorosos y correspondientes a la dignidad de los hombres libres..$^{50}$

Según el diputado Florencio Castillo, el nuevo emperador debía ser llamado Príncipe del Anáhuac porque "ese nombre tiene el prestigio de la antigüedad y debe lisonjear a los indígenas por ser propio de un idioma y de un país suyo; que a más de eso no huele a feudalismo porque hoy se da el nombre de Anáhuac a todo el imperio mexicano". ${ }^{51}$ La discusión que se generó en el congreso sobre qué nombre darle al príncipe implicó interesantes debates entre los distintos representantes de las provincias. El diputado Argándar propuso que se llamara Príncipe de Mechoacán ${ }^{52}$ por ser ahí cuna de los más importantes héroes de la independencia; José Guridi y Alcocer sugirió Príncipe de Iguala por ser el lugar donde se manifestó el grito de independencia; $; 3$ el diputado de Jalisco, Juan de Dios Cañedo, se opuso a que se diera el mote de Príncipe del Anáhuac porque la voz de Anáhuac remitía a las propiedades de Moctezuma que representaban sólo una parte del inmenso territorio nacional, ${ }^{44}$ sostuvo que si se aprobaba Príncipe de Mechoacán se haría asociación con el espíritu de provincialismo provocando el enojo de las demás provincias:

ya siento celos en que se le denomine de Mechoacán. Los méritos que se alegan a favor de esta denominación no carecen de ellos las demás provincias, porque hablando yo de la mío, diré, que si en Mechoacán hubo héroes que dieron las vidas para defender la patria, también los hubo en la mía [...] dígalo la sangre que se derramó en las batallas de Zacoalco, Colima y otras muchas; dígalo la memorable de Calderón y Pajaritos y dígalo, en fin, el fuerte de Mezcala, terror de los realistas.55

Los argumentos por nombrar al emperador de una u otra manera, según la proeza heroica atribuida por los diputados de sus respectivas provincias, fue materia de larga discusión en junio de i822. Esto remite a que desde un principio cada provincia pretendió dar gloria nacional en una especie de sinécdoque donde la parte simbolizara al todo. No podía faltar la posición de Lucas Alamán sobre Guanajuato, por qué no Príncipe de Guanajuato pues ahí se gestó la libertad. ${ }^{56}$ Después de acaloradas discusiones, ningún diputado que pretendía asegurar la gloria para su provincia logró imponer su argumento sobre el resto. Finalmente, quedó aprobado por el congreso que el emperador debía llevar por mote Príncipe Imperial.57 Era el tiempo de Iturbide y así como fue significativa la discusión, también fue significativo el silencio en torno a Hidalgo.

El Príncipe Imperial fue objeto de altos honores en algunas de las ciudades más importantes como en Guadalajara, Zacatecas, México, Puebla; en algunas de ellas el ayuntamiento constitucional mandó la acuñación de 42 medallas del Doctor Agustín I que serían empleadas en la jura en que la ciudad le honraría para perpetuar su memoria. ${ }^{58}$ Fue centro de atención en 
la retórica sermonaria en el breve periodo del imperio mexicano, se reconocieron las bondades de la monarquía constitucional en tanto forma de gobierno que recupera a los mejores hombres para la dirección de su pueblo y, al mismo tiempo, porque se introduce la práctica del derecho al voto, pero esas bondades quedaron sepultadas en la retórica cívica republicana unos cuantos años más tarde con la entrada de la vida republicana. ${ }^{92}$ Las piezas oratorias dedicadas a la consumación de la independencia y a la figura de Iturbide concitaron a la unidad de españoles y americanos, a diferencia de la retórica republicana dedicada al grito de Dolores en la que enfatizó su separación. .60

De Iturbide se puso hincapié en su carácter, sus cualidades militares y la capacidad que tuvo para alcanzar la independencia y lograr la unidad; algunos discursos pronunciados en el obispado de Michoacán, estudiados por Carlos Herrejón, encumbraron a Iturbide soslayando al

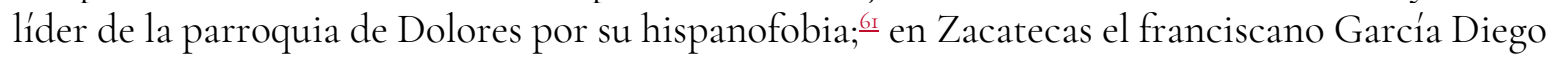
reconoció el influjo de la virgen de Guadalupe y su intercesión ante Dios,

por eso determinó el Señor mismo, bueno y poderoso, que se levantase de entre nosotros un nuevo Moisés, que sacándonos de la esclavitud de Faraón, nos condujese a la hermosa y feliz tierra de Cannan [...] suscitó Dios de entre todos los hijos de la América al grande, al glorioso, al religiosísimo don Agustín de Iturbide, para que quitara a este pueblo las pesadas cadenas con que se hallaba esclavizado y nos pusiese en libertad dichosa.

Ni una palabra dedicada a Hidalgo y al 16 de septiembre. ${ }^{62}$

Qué recordar y a quién encumbrar como benemérito hijo de la patria, fue una constante en las preocupaciones de los legisladores en I822. El conjunto de los diputados mexicanos habían sido partícipes, de manera directa o indirecta, de los años del teatro de la guerra; pensar la nación en aquel entonces presupuso hacer un balance de la historia reciente: "la historia y mi propia experiencia me han enseñado lo que son las revoluciones", ${ }_{33}$ expresaron en el recinto legislativo, aunque el tiempo transcurrido no hubiera rebasado poco más de una decena de años. Desde la tribuna de aquel congreso constituyente se repasaron los méritos y episodios vividos en la guerra inmediata, de quienes sacrificaron sus vidas en pos de la libertad y de la nación. La nación fue concebida entonces como aquella realidad forjada después de la convulsión armada. El resultado de las armas había sido la fragua de la nación. Un rasgo semántico de gran fuerza simbólica en el uso del vocablo nación con la consumación de la independencia fue recuperar el sentido de nacimiento, pero no sólo como lugar de nacimiento, sino como hecho histórico originado desde América, desde el Anáhuac, para dar identidad. Nación nacida.

La nueva nación fue resultado de una guerra; su epicentro era la Nueva España. La vieja patria quedaba a más de dos mil leguas de distancia y la experiencia constitucional de la nación española se constituyó, desde la oratoria cívica en México durante la década de i8zo, en un alejado referente. El ya aludido fraile zacatecano, en su sermón dedicado a la consumación de la independencia, aseguraba que ese rey distante dos mil leguas de América, nada sabía de la situación que se vivía, pues sus aduladores hacían todo por malformar su opinión, “¿nuestras 
quejas y lamentos llegarían a sus oídos teniendo que pasar por tantas manos sospechosas? [...] Señores: la repetida experiencia de tantos años nos ha enseñado que, o los reyes ignoraban del todo nuestra situación triste, o si la sabían y querían aliviarnos, sus subalternos no obedecían sus órdenes". ${ }^{64}$

¿Quiénes fueron considerados héroes nacionales en I822? Nicolás Bravo, Vicente Guerrero, Miguel Hidalgo, José María Morelos fueron reconocidos como los Caudillos de la Independencia. Después se discutió quiénes habían sido más heroicos, si los iniciadores, los continuadores, o los consumadores. Hidalgo fue el ejemplo más ilustrativo de quienes iniciaron y gran parte de su mérito se debió a que su llamado representó el rompimiento del antiguo orden español; fueron el primero en dar el Grito de libertad; en opinión del diputado de la Llave, los primeros insurgentes como el cura Hidalgo "rompieron contra un gobierno entonces más poderoso, y tuvieron que luchar contra el Tribunal de la Inquisición que coadyuvó cuanto pudo para resistirla". .5

Qué se tenía después de once años de guerra: una independencia sí, pero monstruosa, porque en medio de convulsiones, confusiones y con una nación embrionaria, todo estaba en realidad por hacerse. Cuál fue el sentido que se le dio al vocablo héroe por los diputados en i822: un mérito consagrado a determinadas personas que habían muerto por la causa de la independencia, por ende, reconocerlos como tales era una muestra de gratitud por su sacrificio. Desde este punto de vista, otros momentos de la historia fueron desplazados de aquella denominación ${ }^{66} \mathrm{y}$ héroe fue aquel que luchó en la inmediata guerra de independencia de i8ro. Buscando disminuir la importancia de Agustín de Iturbide, héroes considerados Padres de la Patria, fueron entonces los iniciadores de la guerra de i8ro.

Significativa resulta la manera en que se inicia la tradición cívica septembrina con una serie de contradicciones y desacuerdos, a quién dedicar septiembre: a Hidalgo o a Iturbide. Después de las primeras conmemoraciones en tiempos de guerra, durante el primer imperio, la figura de Hidalgo quedó en la sombra; a partir de 1823 es a Iturbide a quien se dejará de mencionar en sermones y oraciones cívicas. Con el decreto del 8 de abril de i 823 en que se declararon insubsistentes el Plan de Iguala, los Tratados de Córdoba y el decreto del 24 de febrero de i822, hubo un cambio en la simbología nacional, el i4 de abril de i 823 se decretó "que el escudo sea el águila mexicana parada en el pie izquierdo sobre un nopal que nazca de una peña entre las aguas de la laguna, y agarrando con el derecho una culebra en actitud de despedazarla con el pico". El ig de julio de i 823 el congreso publicó el decreto en donde se reconocían como "beneméritos de la patria en grado heroico" y colocados con letras de oro en el salón de Cortes, los nombres de Miguel Hidalgo, Ignacio Allende, Juan Aldama, Mariano Abasolo, José María Morelos, Mariano Matamoros, Leonardo y Miguel Bravo, Hermenegildo Galeana, José Mariano Jiménez, Francisco Javier Mina, Pedro Moreno y Víctor Rosales. Asimismo se decretó que todos aquellos que hubiesen participado en servicios a la patria, que si bien no estuvieron en los campos de batalla, aunque sí en la prisión para "sostener la independencia" en aquellos años de guerra, podrían obtener empleos con la recomendación de jefes conocidos; por su parte los que recibieron indulto o prestaron sus servicios a la "causa de España" quedaban excluidos de tal distinción. 
El surgimiento de nuevas asociaciones como las sociedades de amigos del país o las juntas patrióticas en distintas ciudades del territorio promovieron las celebraciones septembrinas y, al mismo tiempo, la destrucción de los antiguos símbolos que recordaran la presencia española. Emblemas, banderas, blasones, escudos de armas fabricados en cantera que recordaran cualquier linaje español, fueron blanco de sus ataques colocándoles, por decreto, un velo para ser cubiertos porque "aquellos monumentos con que los señores reyes de España premiaban a nuestros antiguos nobles su avezamiento a la esclavitud, sus servicios feudales y el dinero que les mandaban todo en perjuicio de nuestra malhadada patria [...] la delicadeza democrática exige que se piquen y destruyan enteramente". ${ }^{67}$

La hispanofobia desatada por el culto cívico republicano no reconoció que desde la Constitución de Cádiz y su vigencia en dos periodos del pasado reciente, había eliminado el ritual del paseo del real pendón como símbolo de igualdad entre los españoles de ambos hemisferios; pese a que en varios temas la Constitución de I8I2 permanecía vigente con la entrada de la vida republicana y su Constitución federal de i 824 , las antiguas plazas de armas llamadas de la Constitución precisamente para recordar la gaditana, fueron perdiendo esa referencialidad. Aquellos años de mutación simbólica representaron una tenaz guerrilla semiológica entre formas de gobierno monárquica y republicana. De la misma manera se prohibieron por algunas Sociedades Patrióticas de Amigos, antiguas tradiciones como la representación de la guerra de moros y cristianos llamadas también morismas; algunos comerciantes fueron denunciados en la prensa por poner a la venta pañuelos "con un águila pintada en acción de estar rendida por un coyote que la tiene agarrada por el pescuezo [...] sabiendo por toda la república cuál sea la significación de la palabra coyote se ha creído que quien mandó pintar esos pañuelos creyó de este modo tomar venganza de los americanos y ultrajarlos, como suele decirse, con sus mismas armas". $\underline{68} \mathrm{La}$ virgen conquistadora en algunas ciudades fue rechazada porque no podía concebirse una virgen aliada a la causa de los españoles que vinieron a esclavizar a los indios de estas tierras americanas. Era un contrasentido imaginar una virgen que echara un puño de tierra a los ojos de los indios desde lo alto del cerro para quitarles la ceguera de la idolatría y convertirlos al cristianismo. Su lugar ya lo tenía ocupado la advocación guadalupana como la madre protectora de los mexicanos.

En medio de los avatares y los riesgos de fragmentación política y territorial, se fue creando la república mexicana. Había que homogeneizar partiendo de grandes líneas vectoras que armaran la nación: la religión católica como la única del Estado mexicano; el uso de la lengua castellana; el apego al patronato de la virgen de Guadalupe y el i2 de diciembre como día de fiesta nacional; la definición de los límites del territorio; los rituales septembrinos; y la narrativa histórica como edición de la memoria que forja el recuerdo en común. El Miguel Hidalgo concreto fue cediendo paso al historiográfico "Padre de la Patria", su "grito" quedó fijado como el acto fundante de la nación mexicana e hizo del pueblo de Dolores su cuna, su punto de partida. Estas líneas fueron columna de la nueva nación e implicaron su redirección histórica, su sentido y razón de ser hacia atrás y hacia adelante. ${ }^{69}$ La nación se fue construyendo, por tanto, como algo inédito, una realidad imaginada mayor, articulada y con posibilidades de articular las tendencias provincianas con sus patrias chicas de "ciudades pequeñas y de horizontes limitados por el campanario de la iglesia"..$^{\circ}$ 
Edición de la memoria: de historias y olvidos

Homogeneizar ha sido una tarea del Estado mexicano para dar cuerpo de nación. El i6 de septiembre se convirtió en el ritual cívico para conmemorar la nación nacida. Una tradición centenaria donde el gobernante en turno lanza los vivas a la patria y a los héroes. Marta Terán, estudiosa de la guerra de insurgencia y de la simbología empleada por el cura Hidalgo, ha analizado la importancia de la figura de la virgen de Guadalupe como patrona de la nación mexicana, los dos lienzos de la virgen tomados por el cura para acompañar su levantamiento, que actualmente presiden la sala de las banderas en el Museo Nacional de Historia, representaron "el concepto de la independencia mexicana". 프a advocación guadalupana asociada a la nación mexicana tiene varios rasgos semánticos: la intención del cura Hidalgo de tomar aquella imagen fue entregarla a uno de sus acompañantes para colocarla al frente de todos, como la cabeza de las tropas rebeldes y la guía del movimiento; con Morelos, la advocación guadalupana se convirtió en protectora de los insurgentes y Patrona de nuestra libertad. La imagen de Guadalupe representa la elección de la madre a sus hijos de América "dáresele a la nación María", ${ }^{2}$ la patrona de la nueva nación, una nación que nace de una guerra, una madre que nace en América. Esta semántica terminó por imponerse frente a los otros sentidos que tuvo la advocación durante el periodo novohispano como patrona de la salud o de la minería. William B. Taylor, después de analizar el culto guadalupano en la Nueva España, advirtió que, derivado de la asociación política de María con los levantamientos, sobre todo, el de la guerra de insurgencia, "se ha dado la impresión de que este mensaje de protesta fue el único en transmitirse, que la Guadalupana fue communitaspara los indígenas a partir de la década de I530, o sea opuesta a la estructura y a todo lo jerárquico, paternalista o hispánico". ${ }^{73}$

El patronazgo guadalupano de la nación mexicana se convertirá también, en el elemento por excelencia de la identidad racial de esta nueva nación. Los rasgos morenos de la Guadalupana reflejaron más que nunca el "cuerpo de la nación". ${ }^{74}$ La Patrona de la Libertad convocaba una nueva y homogénea forma de verse a sí mismo como mexicano, un deber ser vinculado a la apariencia de los cuerpos que hacían esta nación. Forma nueva, porque el moreno mestizo que en el visto entonces como oscurantismo colonial, era "bastardo de sangre impura", en el nuevo marco devenía en "el sujeto central histórico de la construcción y unificación nacionales". 75 El elemento racial, como parte indisoluble de las concepciones nacionales modernas, encontraría en esta imagen una de sus principales herramientas de difusión y socialización.

Durante el curso de los primeros años de la república se desarrolló en la narrativa cívica una visión periodizada de la historia de México. Se buscó ratificar los orígenes de la patria elaborando visiones apologéticas que respondieran y confrontaran la presencia española. El mundo indígena en abstracto fue una de las principales fuentes para promover la idea de nación con raíces históricas de larga duración. La historia empezaba justo con la tradición prehispánica y no en I52I con la llegada de los españoles como lo había reproducido buena parte de la literatura novohispana a través de la oratoria sagrada. ¿Qué se dijo de aquel mundo indígena olvidado durante el periodo colonial y ahora resucitado para armar la nueva nación mexicana? La América, en la retórica liberal republicana, representaba un mundo pacífico, armonioso, de "dicha inefable [...] jeroglíficos que apenas se descifran, nos conservan alguna huella de la marcha 
de los indígenas al estado de cultura en que brillaron desde el siglo XII", afirmó José María Tornel en la ceremonia de aniversario de la independencia en $1827 \cdot{ }^{76}$

El sentimiento de hispanofobia se fue desarrollando en la medida en que evolucionó la admiración a las raíces mitológicas indias. Las voces y paisajes con ascendencia indígenas fueron parte de representaciones emblemáticas para ser usadas en pos de la hispanofobia: "iOh Citlaltépetl, monte soberbio de mi patria! ¡Los pueblos famosos que miraste nacer desaparecen como un sueño!"’z Paradójicamente, los argumentos empleados para edificar al mundo indígena fueron imágenes de destrucción: "bien pronto lloraron los tabasqueños su condescendencia con los mentidos hijos del sol; y bien pronto cayeron sus templos, fueron saqueadas sus chozas y rompieron sus pechos el plomo y el acero destructor". ${ }^{88}$ La historia no inició, por tanto, con la llegada de los españoles a América. Éste fue un momento enmarcado en los teatros de guerra y violencia continuados por explotación, maltrato e injusticia. Plumas de otros tiempos como la de Sigüenza y Góngora en el siglo XVII, Francisco Xavier Clavijero en el XVIII, Alexander von Humboldt a inicios del XIX, habían mostrado al mundo que América podía escribirse de otro modo, de cerca, caminándola, reconociendo sus paisajes, admirando sus manifestaciones culturales, lo que permitía apreciar la importancia de sus repúblicas, la diversidad biológica y ambiental, el esplendor del México antiguo, como lo llamó Clavijero.

Denominador común de los discursos septembrinos fue la insistencia en recordar los siete pecados capitales de los españoles: avaricia, ira, lujuria, gula, envidia, pereza, vanidad: la retórica cívica no se detuvo en aquellos siete pecados, agregó en su conocida lista la maldad, la saña, la soberbia; Juan Francisco de Azcárate la llamó "la caduca, paralítica e impotente España".72 Todo eso había que recordarlo una y otra vez, año con año. Recordar era reprochar, condenar. Eso no podía quedarse en el olvido. La cultura del agravio fue el mejor paladín de la hispanofobia. Desde la plaza mayor de la Ciudad de México, Francisco Manuel Sánchez de Tagle se preguntaba: “qué éramos ha veinte años? ¿lo recordáis amigos? Tal vez no, porque almas generosas como las de los mexicanos, pasado el mal y los agravios, los entregan absolutamente al olvido". 으 Recordar y no olvidar fue una de las necesidades más apremiantes de aquella retórica republicana en un ejercicio que más se parecía a un ajuste de cuentas que a un inocente repaso por la historia de México. Recordar se volvió sinónimo de juzgar tanto los actos heroicos, las herejías de la historia y las nuevas formas de liberación social, como fue el caso de la puesta en libertad de los que aún permanecían en la esclavitud y fueron liberados los días en que México cumplía años de nacer. $\cdot$ -

La hispanofobia se vio así estrechamente vinculada al americanismo. Miguel Hidalgo prescribía que "Ninguno se distinguirá en calidad, sino que todos se nombrarán americanos" $\underline{\text { g }}$ y relacionaba la condición de calidad a la reprochable existencia de la esclavitud. No obstante, la existencia concreta de diferencias étnicas en las poblaciones ahora ciudadanas de la nación, exigió siempre al Estado enfocar una buena cantidad de esfuerzos a "inventar una sustancia unitaria" que hiciera inteligible, pero, sobre todo, predicable, la identificación de todos los ciudadanos con una sola nación, un sólo proyecto. En la práctica, la segregación y la distinción tomaron otras formas naturalizándose en la prédica cívica, un ideal simbólico de las características étnicas y raciales de los ciudadanos mexicanos. $\stackrel{8}{3}$ 
La narrativa volvió a editar la historia de México: acomodó las piezas en una estructura mitológica sagrada: el periodo prehispánico fue el paraíso vivido; la época colonial, el paraíso perdido; y la guerra de insurgencia y el correr del siglo XIX, el paraíso recuperado en el que se insistía en discursos y oraciones cívicas la idea de regeneración política para dar cuerpo a la nación con el papel mesiánico del cura Hidalgo. La historia se dividía en tres bloques antagónicos, de cada uno de ellos había que fomentar un conjunto de valores enmarcados en una gran hazaña pedagógica de carácter cívico. Del paraíso indígena vivido se divulgó el orgullo de las raíces; del paraíso perdido el rencor de los vencidos; y del paraíso recuperado la hazaña de la libertad que volvía a vincular de manera armoniosa a la nueva nación, la mexicana, con sus orígenes, los prehispánicos. Y en efecto, esta operación constructiva de la nación encontró la herramienta idónea en el mito, instrumento que permitía aludir de forma simultánea al pasado $\mathrm{y}$ al futuro.

El proceso de negación del viejo orden y de adopción del nuevo abarcó varios años. Pasó más de una década entre la caída de la monarquía española, resultado de la invasión francesa a la península ibérica en 1808 , y la separación definitiva de esos territorios que habrían de convertirse en las naciones hispanoamericanas. El cambio fue particularmente difícil para la mayor parte de los miembros de las elites que habían prosperado y se habían beneficiado del viejo orden; ellos fueron compelidos a renegar de sus vínculos con el antiguo régimen. Muchos de estos individuos se convirtieron en dirigentes de las nuevas naciones. En el proceso de formación de esas entidades políticas, las elites aprovecharon la nueva ritualidad cívica que el i6 de septiembre les daba para borrar sus vínculos con el antiguo régimen, denunciándolo por opresivo y dañino. Los ciudadanos de los nuevos estados rechazaron los símbolos del viejo orden "inventando" nuevos símbolos, héroes y narrativas históricas.

El i6 de septiembre se volvió día emblemático fundacional. En ciudades, villas y pueblos fue motivo para unirse a su conmemoración. Las autoridades estatales y municipales, auxiliadas por las Sociedades Patrióticas, se dieron a la tarea de promover el ritual septembrino. En el mineral de la Sierra de Pinos, en Zacatecas, en la víspera se colocaba media docena de candiles en las casas consistoriales, cuatro cargas de leña repartidas en luminarias alrededor de la plaza pública, cohetes para los juegos artificiales, música con tambora, vihuelas, violines, tambores destemplados, soldados armados con fusiles y lanzas. Día de conmemorar y también de relajar, pues, se aprovechaba para que al menos durante 24 horas se jugara a los naipes de manera ininterrumpida. El significado del evento en la plaza fue sintetizado por el cura párroco desde el púlpito:

Todas las naciones honran a sus héroes y por lo mismo vamos a honrar al nuestro con la misa que es el mayor sacrificio, aunque en otros pueblos sea con más solemnidad estas funciones; aquí la decadencia de la corporación no lo permiten, mas lo que sí les encargo, hermanos míos, es que guardéis la unión, ya que hemos tenido la felicidad de salir de la esclavitud en que nos hallábamos, no vayamos por estas discordias a ser gobernados por otra nación, que no es lo mismo comer y tirarse con los platos, quiero decir que no es lo mismo comer por mano propia que por mano ajena. Y para que tengamos fuerzas, le pido a Nuestra Señora de las Nieves les 
eche su bendición [...] será posible que así se haga memoria de nuestra feliz emancipación que afortunadamente disfrutamos. ${ }^{84}$

Los vocablos de nación y pueblo fueron piezas sustantivas para armar la historia de México en el siglo XIX. El sentido étnico de nación para denotar las naciones chichimecas, aztecas, olmecas, cedió paso al sentido político de nación como el armazón de gobierno y comunidad política que permitía dar unidad a un conjunto diferenciado de habitantes en un territorio determinado. De la misma manera, el uso del término "pueblos", en su acepción de conjuntos corporativizados, dejó paso a la noción abstracta de pueblo. Aquellos pueblos diferenciados como "cuerpos orgánicos" se refundieron en la nueva invención republicana llamada pueblo. En pos de la homogeneidad y uniformidad, la noción de pueblo sirvió para dar unidad nacional en detrimento de la diversidad étnica y social. En el sentido político de pueblo cabían todos, pero se perdían las especificidades culturales. Se invocaba su nombre a la vez que se limitaba su participación concreta. El pueblo fue la nueva comunidad política con valores y rasgos comunes como las tradiciones, el sacrificio, la heroicidad; el mexicano fue identificado a través de paralelismos con el pueblo hebreo como analogía del pueblo liberado. $\frac{85}{5}$ pueblo era un "nosotros" que incluía varios tiempos históricos, disímiles actores y territorios; ese nosotros tenía tierra, pertenencia, historia y recuerdo, de ahí la eficacia del discurso cívico como constructor de valores de ese nuevo sujeto colectivo. El nosotros se opuso a los otros, cualquier grupo o nación extranjera que fuere; como lo sugiere Mónica Quijada:

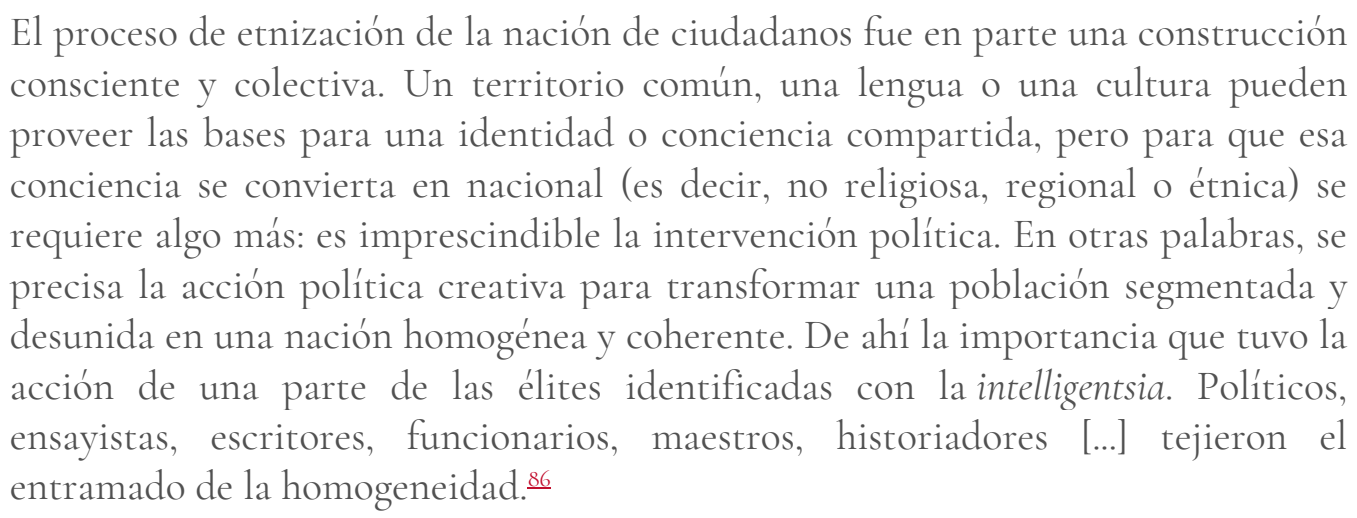

En la retórica republicana y bajo un hálito de mesianismo bíblico, el pueblo adquirió con la guerra de insurgencia la liberación de las cadenas que lo oprimían y ahora era el principal sujeto del beneficio de la regeneración política. Atrás también quedaban sustantivos como plebe, chusma, amotinados, vulgo. ${ }^{87}$ La guerra venía a ser también una especie de bisagra que tomaba lo mejor de la tradición ilustrada frente a la nueva era republicana.

La guerra de insurgencia fue considerada por los oradores de la república como el gran evento histórico que marcó un parteaguas en el devenir de la sociedad mexicana. En eso estuvieron de acuerdo escritores, ensayistas, historiadores y funcionarios como sostiene Mónica Quijada; aquellos que participaron en recordar la independencia tuvieron varios rasgos comunes en torno a cuáles elementos había que escribir para fijarlos en la memoria colectiva y qué pasajes de la historia había que dejar en el olvido. 
No podía reproducirse la idea de que España y la monarquía en su conjunto habían demostrado sus principios liberales a través de la tradición intelectual iusnaturalista e ilustrada. Tampoco debía propagarse el hecho de que la Constitución de i8I2 representaba un documento liberal y revolucionario de vanguardia. El liberalismo español expresado en las Cortes de Cádiz fue silenciado en la retórica republicana. Si aquél fue un ejercicio por transformar la monarquía y hacerla viable a través de la elaboración de un código constitucional, la imagen reproducida en las arengas cívicas fue la del peso del absolutismo, es decir, una caduca monarquía gobernada por la voluntad unipersonal de su déspota monarca: "un héroe conmovió la tierra, atacó al despotismo, lo venció y levantó con sus manos sobre las ruinas sangrientas de una colonia, el edificio inmortal de la nación mexicana". $\underline{\underline{8}}$ Las hazañas del héroe, según esta narración histórica, fueron más potentes que aquel título gaditano de "la soberanía reside esencialmente en la nación". En I829, José María Herrera sentenció desde la Alameda de la Ciudad de México: "Sancionóse y publicóse la Constitución Política de la Monarquía Española en marzo de i8I2, y podemos decir que se sancionó el despojo de nuestros derechos, privando del de representación a una multitud inmensa de americanos"; 9 el orador agregó que la Constitución le sirvió a Félix María Calleja para su propio prestigio, pero México caminó sin ella hacia "el abismo de sus desgracias". ${ }^{\circ}$

La monarquía española dejó de concebirse como la eugénesis de la patria. La que había dado lengua, instituciones, religión, marco jurídico y gobierno. La oratoria cívica reprodujo la imagen de que España era un ente caduco, inerme, obsoleto y paralítico. La nación estaba en América y la patria era reconocida en el conjunto de las provincias que la integraban; la oposición de los tiempos era evidente. La patria española quedaba en el pasado y se anunciaba gracias al paso de un acontecimiento singular como los once años de guerra, la expectativa de una patria propia. El patriotismo se daba en una América doliente, humilde, sacrificada, por ende, merecedora de un futuro promisorio donde el legislador del universo proveía de fruto y destino a la nación mexicana.

El vocablo independencia fue apropiado por la retórica republicana. Una y otra vez fue pronunciada la idea de que la independencia había sido de México hacia España. El inicio y fin de la guerra se enmarcaron en un solo evento: el i6 de septiembre de i8Io. El grito de Dolores fue de independencia y libertad, así pasó a la historia. No se hizo mención en las tribunas públicas que dos años antes, en i8o8, el 2 de mayo, los soldados españoles se enfrentaron con el ejército francés para batir por la independencia de la monarquía española con respecto a las pretensiones napoleónicas de imponer su soberanía.

Si bien en las discusiones parlamentarias se reconoció la importancia de Morelos al grado de considerarlo padre de la patria, en la retórica septembrina Hidalgo fue el principal protagonista de la narrative histórica. Sus actos heroicos fundaron y dieron paternidad a la nueva nación. En cambio, debía guardarse el hecho de que antes habían sido considerados por las Cortes de Cádiz como padres de la patria a los soldados españoles del 2 de mayo. ${ }^{21}$

Según las oraciones cívicas y patrióticas septembrinas, los motivos de la insurgencia radicaban en la propia Nueva España; uno tenía que ver con la identidad étnica: la desigualdad entre 
criollos y peninsulares, en especial, la escasa o nula participación de los criollos en los cargos públicos; el otro tenía relación con aspectos de carácter social y laboral donde estaban implicados de manera vertical dos actores que, según estas piezas oratorias, nada tenían en común; españoles explotadores e indígenas oprimidos, sujetos al maltrato, a la humillación y a la continua cultura de los agravios. Los discursos mostraron escasas referencias a la invasión de Napoleón a España; las explicaciones de los orígenes de la guerra de insurgencia eran sociales y no políticas. ${ }^{92}$ I 808 no podía explicar el inicio de la guerra en I8Io porque en aquel año se registraron acontecimientos que, si bien fueron decisivos para el conjunto monárquico español, no tuvieron ese impacto en los reinos de ultramar. Por tanto, la explicación de la guerra de i8ro es interna, interétnica; el epicentro es la Nueva España. En tal sentido, los años de guerra aparecieron como un suceso extraordinario que aislaba al virreinato de una visión general en tanto parte de un conjunto monárquico mayor, antesala de la historiografía de corte nacionalista. La consecuencia que derivó de esta explicación intestina es que de la guerra de insurgencia en i8ıo surgió la nación mexicana.

Frente a los pasajes oscuros y silenciados de manera intencional por los oradores desde la tribuna, se iluminaron en cambio con gran fuerza los principales momentos que habían dado heroicidad a la nación mexicana. La intención era separarse de España y uniformarse como nación con identidad propia. Esto se dijo a través de profusas y alegóricas descripciones en los discursos cívicos septembrinos.

Hidalgo pasó de líder social a padre de la patria y héroe nacional. Todos los atributos positivos: magnánimo, prudente, sabio, ilustrado; Wenceslao Barquera afirmó que el Grito de Dolores había encendido el fuego santo que nunca se extinguiría. ${ }^{23}$ Los discursos septembrinos compartieron la idea de que Hidalgo supo desde el principio el rumbo que tomaría la guerra, tenía claros sus objetivos, "conmovió a la tierra", "atacó al despotismo". José María Tornel describió los afanes del héroe de Dolores:

El párroco meditaba a solas los medios de vengar a su patria querida, y su mente fatigada repasaba los afanes, los sacrificios, los obstáculos de una empresa en que se lucharía con la fuerza, con el prestigio de una dominación omnipotente, arraigada en la serie de algunos siglos, con las preocupaciones políticas y religiosas, con el hábito de doblar la rodilla a dioses distantes y de atender como oráculos a ministros pérfidos suspicaces y falsarios. Hidalgo se decide, porque siempre vence el que sabe morir. ${ }^{94}$

Después vinieron los Matamoros, Bravos, Victorias, Guerreros y Galeanas que sostuvieron el espíritu heroico de los Hidalgos, Morelos y Allendes. Empero, nada se dijo de la matanza de españoles en Guanajuato y Guadalajara por el ejército insurgente, ni de las divisiones entre Hidalgo y Allende.

En cambio los Callejas, Álvarez y Trujillos fueron pintados con lodo y venganza; entre otros de los calificativos se les llamó crueles, sanguinarios, vengadores, genios infernales, habitantes del averno. Si la descripción fue un excelente recurso literario para la caracterización de los héroes, 
también lo fue para los antihéroes como Calleja y los jefes realistas: "Calleja degüella en Aculco, donde tuvo su primer ensayo, cinco mil hombres inermes; entra enseguida a Guanajuato y allí sacrifica sin resistencia catorce mil víctimas de todos sexos y edades. Esta conducta le mereció el empleo de mariscal de campo, y esta conducta bárbara sirvió en adelante de modelo a los demás jefes realistas". ${ }^{25}$

Ningún orador pronunció los motivos que tuvo Calleja para defender a la monarquía ni sus convenientes lazos de lealtad con el constitucionalismo liberal. Quedó en el olvido la inteligencia militar del jefe realista, su capacidad de movilización y dominio; su control sobre el territorio. No se dijo nada sobre sus evidentes victorias y el dominio de la contrainsurgencia desde los primeros meses de iniciada la guerra. Tampoco se mencionó que los restauradores del orden, como Calleja, habían sido considerados beneméritos por las Cortes de Cádiz al defender a la monarquía de las conmociones sociales y políticas ocurridas en América. Escenas de maldad fueron la paráfrasis del líder contrainsurgente: "Aparecieron al mismo tiempo los Venegas, Callejas y Trujillos para oprobio de los españoles e ignominia de los americanos, sin otras instrucciones políticas que el arte funesto del asesinato público y así ultrajaron los derechos más sagrados de la naturaleza y la razón negándose a prestar oído a nuestros caudillos". ${ }^{6}$

Desde la cultura cívica republicana, la guerra de insurgencia fue de liberación. El pasado quedaba ceñido en "los cuadros de nuestros males". La explicación de la historia se sustentó en la trilogía héroes, providencia y pueblo. De ahí emergía la nueva nación. Estas generaciones de políticos, funcionarios y escritores de la naciente república compartieron la disolución del antiguo régimen, la violencia de una guerra, el embrión de una nueva nación.

\section{Consideraciones finales}

El proceso que dio forma a la narrativa de la nación mexicana y su retórica cívica e historiográfica se nutrió del hacer mismo de quienes se enfrentaron a la modernidad que implicaba, justamente, incorporarse a la dinámica de los nacientes estados nacionales modernos que, como se ha dicho aquí, exigió operaciones de reflexión, discusión y edición del relato histórico y la resignificación de su propio sentido. En este proceso protagonizado por las elites políticas e intelectuales, la selección y entronización de sujetos en próceres heroicos, la reescritura del relato nacional y la redefinición de sus grupos sociales en términos étnicos y raciales fueron elementos fundamentales para anclar el ser y deber ser de la nación mexicana. Hubo desde luego un sin fin de elementos más en la compleja trama de acontecimientos y contextos que tejieron esta primera empresa del poder decir y hacer a la nación. Sin embargo, los elementos antes señalados reclaman, por su fuerte calado en la cultura política de las generaciones posteriores a lo largo del siglo XIX y XX, su lugar privilegiado en el análisis.

Por lo que respecta al pilar de la referencia étnica y racial, los primeros esfuerzos por definir la forma y la apariencia de los cuerpos de la nación encontrarían su principal herramienta en los instrumentos científicos que la segunda mitad del siglo XIX otorgaría a los estados nacionales para justificar, de modo más contundente, la asociación de los modos de ser nacionales a la predestinación biológica. Fue entonces que raza y nación se convirtieron en ese binomio 
indisoluble que, si bien cobró algunos beneficios al prestar un punto de referencia a los procesos culturales identitarios, hoy en día sigue cobrando sus consecuencias más perniciosas.

\section{Agradecimientos}

Agradecemos la detenida lectura, observaciones y sugerencias de los dictaminadores del presente artículo, así como a los integrantes del Seminario de Educación (UAZ-UPN) por sus comentarios.

\section{Referencias}

ALONSO, Martín. I998. Enciclopedia del idioma. Diccionario histórico y moderno de la lengua española (siglos XII al XX) etimológico, tecnológico, regional hispanoamericano. Tomo III. México: Aguilar.

ÁVILA, Alfredo Virginia GUEDEA y Ana Carolina IBARRA, coords. 20Io. Diccionario de la independencia de México. México: Universidad Nacional Autónoma de México.

AZCÁRATE, Juan Francisco de. 1988. "Elogio patriótico que pronuncio... el i6 de septiembre de i826 en la plaza mayor de México el segundo aniversario del grito de independencia”. México: Imprenta del Águila, i826. Tomado de Ernesto de la Torre Villar. La conciencia nacional, 3I-40.

BARQUERA, J. Wenceslao. I825. "Oración patriótica para celebrar el primer grito de libertad en el pueblo de dolores". México: Imprenta de la federación. Tomado de Ernesto de la Torre Villar. La conciencia nacional, 2I-29.

BARRAGÁN Y BARRAGÁN, José. I980. Actas constitucionales mexicanas. Tomo III. Vol. II. México: Universidad Nacional Autónoma de México.

BRADING, David. Selección y estudio introductorio. 2005. Nueve sermones guadalupanos (16611758). México: Centro de Estudios de Historia de México Condumex.

CAÑDO GAMBOA, Sergio A. 200I. Los festejos septembrinos en San Luis Potosí. Protocolo, discurso y transformaciones, 1824-1847. San Luis Potosí: El Colegio de San Luis Potosí.

CASTILlO LEDÓN, Luis. 2003. Hidalgo: la vida del héroe. México: Cámara de Diputados, Fondo de Cultura Económica.

"Catecismo político arreglado a la Constitución de la Monarquía Española, para ilustración del pueblo, instrucción de la juventud y uso de las escuelas de primeras letras". ı8 82 . Madrid: Oficina de Collado.

CHIARAMONTE, José Carlos. 1999. Nación y Estado en Iberoamérica. El lenguaje político en tiempos de las independencias. Buenos Aires: Editorial Sudamericana.

Relaciones Estudios de Historia y Sociedad, vol. XL, núm I57, 2019 
CHUST CALERO, Manuel. 1999. La cuestión nacional americana en las Cortes de Cádiz. Valencia: Centro Francisco Tomás y Valiente, Universidad Nacional Autónoma de México.

2007. "Un bienio trascendental: i808-i8ro. "En La eclosión juntera en el mundo hispano, coord. Manuel Chust Calero, II-50. México: Fondo de Cultura Económica, El Colegio de México, Fideicomiso Historia de las Américas.

CHUST, Manuel y Víctor MÍNGUEZ, eds. 2003. La construcción del héroe en España y México, 17891847. Valencia: Universitàt de València, El Colegio de Michoacán, Universidad Veracruzana, Universidad Autónoma Metropolitana.

Cortes Generales y Extraordinarias, 24 de septiembre de 1810. Noticias y sucesos dignos de mención referentes a esa época. I896. Cádiz: Talleres tipográficos de Manuel Álvarez.

Diario de Sesiones de las Cortes Generales y Extraordinarias, 8 de abril de i8Ir. 2005, Edición digital. Alicante: Biblioteca virtual Miguel de Cervantes Saavedra.

Diccionario de autoridades. 2002. Edición facsimilar. Tomo II. Madrid: Gredos.

ESCOBEDO DELGADO, Martín. 20r4. José Miguel Gordoa. El drama de la transición política (17771832). México: Poder Legislativo del Estado de Zacatecas, Departamento de Estudios Históricos de la Arquidiócesis de Guadalajara.

FEIJOO, Benito Jerónimo. 2002. "Honra y provecho de la agricultura". Teatro crítico universal. Selección. Madrid: Biblioteca Virtual Miguel de Cervantes Saavedra.

GARCÍA DIEGO, Francisco. i822. "Sermón que en la solemnísima función que hizo este Colegio de N.S de Guadalupe en acción de gracias por la feliz conclusión de la independencia del Imperio Mexicano dijo ... El día in de noviembre de I82r". Guadalajara: Imprenta de Mariano Rodríguez.

GOLDMAN, Noemí y Gabriel DE MEGLIO. 20o8. "Pueblo/pueblos". En Lenguaje y revolución. Conceptos políticos clave en el Río de la Plata, 1780-1850, ed. Noemí Goldman. Buenos Aires: Prometeo Libros.

GÓMEZ, Jorge y Ma. Eugenia SÁNCHEZ. 20r. La ideología mestizante, el guadalupanismo y sus representaciones sociales. Una revisión crítica de la identidad nacional. Puebla de los Ángeles: Universidad Iberoamericana.

GUARISCO, Claudia. 20r. La reconstrucción del espacio político indígena. Lima y el Valle de México durante la crisis de la monarquía española. Castelló de la Plana: Universitàt Jaume I.

GUEDEA, Virginia. 1993. "Nueva España". En La eclosión juntera en el mundo hispano, coord. Manuel Chust Calero, 84-I04. México: Fondo de Cultura Económica, El Colegio de México, Fideicomiso Historia de las Américas, 2007.

Relaciones Estudios de Historia y Sociedad, vol. XL, núm I57, 2019 
GUERRA, François-Xavier. 1993. Modernidad e independencias. Ensayos sobre las revoluciones hispánicas. México: Fondo de Cultura Económica, MAPFRE.

ITA Y PARRA, Bartolomé. 2005. "El círculo del amor formado por la América Septentrional jurando a María Santísima en su imagen de Guadalupe la imagen del patrocinio de todo su rey. Sermón panegírico que predicó en el día de su aparición, i2 de diciembre de 1746". En Nueve sermones guadalupanos (1661-1758), selección y estudio introductorio David Brading, 22I-26r. México: Centro de Estudios de Historia de México Condumex.

HERNÁNDEZ Y DÁVALOS, Juan E. 1985. Historia de la guerra de Independencia de México. Vol. I. México: Instituto Nacional de Estudios Históricos de las Revoluciones de México.

HERREJÓN PEREDO, Carlos. 200o. "Construcción del mito de Hidalgo". En El héroe entre el mito y la historia, ed. Federico Navarrete Linares y Guilhem Olivier, 235-249. México: Centro de Estudios Mexicanos y Centroamericanos.

2003. Del sermón al discurso cívico. México, 1760-1834. México: El Colegio de Michoacán, El Colegio de México.

. 20io. Hidalgo, maestro, párroco e insurgente. México: Editorial Clío.

2015. Morelos. Vol. I. Zamora: El Colegio de Michoacán.

HERRERA, J.M. I829. "Oración patriótica que pronunció ... el I6 de septiembre de i829, aniversario del grito de Dolores". México: Imprenta del Águila. Tomado de Ernesto de la Torre. La conciencia nacional, 63-70.

"Himno Patriótico". "Cádiz. Día ig de marzo de i8I4". Miscelánea, s/e.

HOBSBAWN, Eric. 1998. Naciones y nacionalismo desde 1780. Barcelona: Crítica.

MOLINER, María. 2007. Diccionario de uso del español. Tomo II. Madrid: Gredos.

La diputación provincial de la Nueva Galicia. 2004. Edición y sumario Beatriz Rojas. Estudio introductorio Jaime Olveda. México: Instituto Mora, Universidad de Guadalajara.

LANDAVAZO, Marco Antonio. 200I. La máscara de Fernando VII. Discurso e imaginario monárquicos en una época de crisis. Nueva España, 1808-1822. México: El Colegio de México, Universidad Michoacana de San Nicolás de Hidalgo, El Colegio de Michoacán.

LEMOINE, Ernesto, Horacio LABASTIDA y Óscar CASTAÑEDA, ed. y comp. 20io. Documentos para la historia del México independiente, 1808-1938. México: Miguel Ángel Porrúa. 
MARTÍNEZ MARINA, Francisco. I8I3. Teoría de las Cortes o grandes juntas nacionales de los reinos de León y de Castilla. Madrid: Imprenta de Fermín Villalpando.

"Plan del gobierno americano entregado por Miguel Hidalgo a José María Morelos", 3I de octubre I8Io http://www.biblioteca.tv/artman2/publish/ı8Io_II5/Plan_del_Gobierno_Americano_en tregado_por_Miguel_Hidalgo_a_Jos_Mar_a_Morelos_y_expedido_por_ste.shtml.

PÉREZ VEJO, Tomás. 2008. "El problema de la nación en las independencias americanas: una propuesta teórica". Mexican Studies/ Estudios Mexicanos XXIV(2): 22I-244.

PORTILLO VALDÉS, José María. 200o. Revolución de nación. Orígenes de la cultura constitucional en España, 1780-1812. Madrid: Centro de Estudios Políticos y Constitucionales.

QUIJADA, Mónica. 20oo. Homogeneidad y nación. Con un estudio de caso: Argentina, siglos XIX y $X X$. Colección Tierra Nueva e Cielo Nuevo. Madrid: Consejo Superior de Investigaciones Científicas.

- 2003. “Qué nación? Dinámicas y dicotomías de la nación en el imaginario hispanoamericano". En Inventando la nación. Iberoamérica, siglo XIX, coordAntonio Annino y François-Xavier Guerra, 287-315. México: Fondo de Cultura Económica.

RAMÍREZ, Fausto. 2003. "Hidalgo en su estudio: la ardua construcción de la imagen del Pater Patriae mexicano". En La construcción del héroe en España y México, 1789-1847. ed. Manuel Chust y Víctor Mínguez, i89-209. Valencia: Universitàt de València, El Colegio de Michoacán, Universidad Veracruzana, Universidad Autónoma Metropolitana.

RODRÍGUEZ ORDÓÑEZ, Jaime E. 1996. La independencia en la América española. México: Fondo de Cultura Económica, El Colegio de México, Fideicomiso Historia de las Américas.

ROJAS NIETO, Beatriz. 2005. Documentos para el estudio de la cultura política de la transición: juras, poderes e instrucciones. Nueva España y la Capitanía General de Guatemala, 1808-1820. México: Instituto Mora.

RUIZ GUADALAJARA, Juan Carlos. 2004. Dolores antes de la Independencia: microhistoria del altar de la Patria. Zamora: El Colegio de Michoacán, El Colegio de San Luis.

SÁNCHEZ DE TAGLE, Francisco Manuel. i83o. "Arenga cívica que pronunció el i6 de septiembre de I830, aniversario del glorioso grito de dolores”. México: Imprenta del Águila. Tomado de Ernesto de la Torre, La conciencia nacional, 75-88.

TANCK DE ESTRADA, Dorothy. 2013. "Los catecismos políticos: de la Revolución francesa al México independiente". En Independencia y educación. Cultura cívica, educación indígena y literatura infantil. Series Antologías. Dorothy Tanck de Estrada, 249-266. México: El Colegio de México. 
TAYLOR, William F. 2003. "La virgen de Guadalupe en la Nueva España: una investigación sobre la historia social de la devoción mariana". En Entre el proceso global y el conocimiento local. Ensayos sobre el Estado, la sociedad y la cultura en el México del siglo XVIII. William F. Taylor, 389427. México: Universidad Autónoma Metropolitana, Conacyt, Miguel Ángel Porrúa.

TENORIO TRILLO, Mauricio. 1999. Argucias de la historia. Siglo XIX, cultura y América Latina. México: Paidós.

TERÁN, Marta. 2oro. "Símbolos, emblemas e imágenes de los insurgentes y de los realistas". En Diccionario de la independencia de México, coord. Alfredo Ávila, Virginia Guedea y Ana Carolina Ibarra, 207-213. México: Universidad Nacional Autónoma de México.

TERÁN FUENTES, Mariana. 20i2. Por lealtad al rey, a la patria y a la religión. Zacatecas, 1808-1814. México: Fondo Editorial Estado de México.

TORNEL, José María. i827. "Oración pronunciada el día I6 de septiembre de I827, por acuerdo de la junta de ciudadanos que promovió la mayor solemnidad del aniversario de nuestra gloriosa independencia". México: Imprenta del Águila. Tomado de Ernesto de la Torre, La conciencia nacional, 4I-5I.

TORRE VILLAR, Ernesto de la. 1988. La conciencia nacional y su formación. Discursos cívico septembrinos (1825-1827). México: Universidad Nacional Autónoma de México.

WADE, Peter. 1998. "Identidad racial y nacionalismo: una visión teórica de Latinoamérica". En Formaciones de indianidad: articulaciones raciales, mestizaje y nación en América Latina, coord. Marisol de la Cadena, 379-402. Popayán: Envión Editores.

ZÁRATE TOSCANO, Verónica. 2004. "La conformación de un calendario festivo en México en el siglo XIX". Conceptualizar lo que se ve. François-Xavier Guerra, historiador. Homenaje, coord. Érika Pani y Alicia Salmerón, i82-2i4. México: Instituto Mora.

2003. "Héroes y fiestas en el México decimonónico. La insistencia de Santa Anna". En La construcción del héroe en España y México, 1789-1847, ed. Manuel Chust y Víctor Mínguez, I33153. Valencia: Universitàt de València, El Colegio de Michoacán, Universidad Veracruzana, Universidad Autónoma Metropolitana.

\section{Notas}

I Diccionario de autoridades, edición facsimilar, tomo II (Madrid: Gredos, 2002).

2 Así empleado por la tradición oral novohispana cuando esas naciones bárbaras establecían defensa contra los españoles en los siglos XVI y XVII.

3 Éste fue el tópico de numerosos sermones guadalupanos durante el siglo XVIII. El caso citado es "El círculo del amor formado por la América Septentrional jurando a María Santísima en su 
imagen de Guadalupe la imagen del patrocinio de todo su rey. Sermón panegírico que predicó en el día de su aparición, i2 de diciembre de 1746 el Dr. Bartolomé de Ita y Parra", en Nueve sermones guadalupanos (1661-1758), selección y estudio introductorio de David Brading, 2I9-26I (México: Centro de Estudios de Historia de México Condumex, 2005).

4 María Moliner, Diccionario de uso del español, tomo II (Madrid: Gredos, 2007).

5 Eric Hobsbawn, Naciones y nacionalismo desde 1780 (Barcelona: Crítica, I998), 23-24.

6 Ibid., 26.

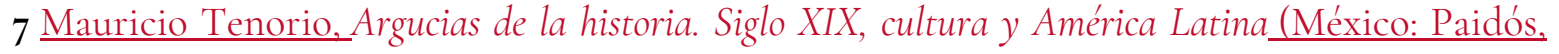
I999), 24-25.

8 Diccionario de autoridades.

9 Martín Alonso, Enciclopedia del idioma. Diccionario histórico y moderno de la lengua española (siglos XII al XX) etimológico, tecnológico, regional hispanoamericano, tomo III (México: Aguilar, Ig88), 3.177.

Io Benito Jerónimo Feijoo, "Honra y provecho de la agricultura", Teatro crítico universal. Selección (Madrid: Biblioteca Virtual Miguel de Cervantes Saavedra, 2002).

I Manuel Chust Calero, "Un bienio trascendental: I808-18Io". En La eclosión juntera en el mundo hispano, coord. Manuel Chust Calero, II-50 (México: Fondo de Cultura Económica, El Colegio de México, Fideicomiso Historia de las Américas, 2007).

I2 François-Xavier Guerra, Modernidad e independencias. Ensayos sobre las revoluciones hispánicas (México: Fondo de Cultura Económica, MAPFR, I993), II5.

I3 Algunas de las investigaciones más representativas que han formado escuela son las obras de Jaime E. Rodríguez O., La independencia en la América española (México: Fondo de Cultura Económica, El Colegio de México, Fideicomiso Historia de las Américas, 1996); François-Xavier Guerra, Modernidad e independencias; Manuel Chust Calero, La cuestión nacional americana en las Cortes de Cádiz, (Valencia: Centro Francisco Tomás y Valiente, Universidad Autónoma de México, 1999); Virginia Guedea, "Nueva España", en La eclosión juntera,coord. Manuel Chust Calero, 84-IO4; José María Portillo Valdés, Revolución de nación. Orígenes de la cultura constitucional en España, 1780-1812 (Madrid: Centro de Estudios Políticos y Constitucionales, 2000); Mónica Quijada, ¿Qué nación? Dinámicas y dicotomías de la nación en el imaginario hispanoamericano", en Inventando la nación. Iberoamérica, siglo XIX, coord. Antonio Annino y François-Xavier Guerra, 287-315 (México: Fondo de Cultura Económica, 2003).

I4 Claudia Guarisco, La reconstrucción del espacio político indígena. Lima y el Valle de México durante la crisis de la monarquía española (Castelló de la Plana: Universitàt Jaume I, 20II), I75-I77. 
I5 "Documentos relativos a la proclamación de Fernando VII como rey de España", en Historia de la guerra de Independencia de México,vol. I, Juan E. Hernández y Dávalos, 495-505 (México: $\underline{\text { Instituto Nacional de Estudios Históricos de las Revoluciones de México, I985). }}$

I6 Marco A. Landavazo, La máscara de Fernando VII. Discurso e imaginario monárquicos en una época de crisis. Nueva España, 1808-1822(México: El Colegio de México, Universidad Michoacana de San Nicolás de Hidalgo, El Colegio de Michoacán, 200i), en especial el capítulo "El contenido de la fidelidad", 97-I34. Mariana Terán, Por lealtad al rey, a la patria y a la religión. Zacatecas, 18081814 (México: Fondo Editorial Estado de México, 20I2).

17 Beatriz Rojas, Documentos para el estudio de la cultura política de la transición: juras, poderes e instrucciones, Nueva España y la Capitanía General de Guatemala, 1808-1820 (México: Instituto Mora, 2005), 89-9I.

I8 La propia naturaleza del evento histórico que aquí se trata ha producido una inmensa historiografía. De entre las múltiples aportaciones disponibles, nos parece que son especialmente ilustrativas las de Carlos Herrejón y Ernesto Lemoine, quienes destacan precisamente la vehemente retórica del grito de Dolores. Tal el caso de las exclamaciones que Carlos Herrejón ha documentado para la historia del Grito de Dolores: poco después, esa misma madrugada, el cura Hidalgo arengó desde el atrio del templo de la parroquia, “¡Hijos míos! ¡Únanse conmigo! ¡Ayúdenme a defender la patria! Los gachupines quieren entregarla a los impíos franceses. ¡Se acabó la opresión! ¡Se acabaron los tributos! Al que me siga a caballo le daré un peso, y a los de a pie, un tostón". Alfredo Ávila, Virginia Guedea y Ana Carolina Ibarra, coords., Diccionario de la independencia de México (México: Universidad Nacional Autónoma de México, 20Io), I94-I97. Por su parte Ernesto Lemoine recupera las siguientes frases como la fórmula del Grito de Dolores: “¡Viva la religión católica! ¡Viva Fernando VII! ¡Viva la patria! y ¡Viva y reine por siempre en este Continente Americano nuestra sagrada Patrona, la Santísima virgen de Guadalupe! ¡Muera el mal gobierno! Esto es lo que oiréis decir de nuestra boca y lo que vosotros deberéis repetir!", "Primera proclama formal de Hidalgo en la que se vierten algunos de sus postulados ideológico-políticos, io de octubre de I8Io". Ernesto Lemoine. Horacio Labastida y Óscar Castañeda, edición y compilación documental, Documentos para la historia del México independiente, 1808-1938 (México: Miguel Ángel Porrúa, 2010), 73.

19 Cortes Generales y Extraordinarias, 24 de septiembre de 1810. Noticias y sucesos dignos de mención referentes a esa época (Cádiz: Talleres Tipográficos de Manuel Álvarez, I8g6).

20 Eric Hobsbawn, Naciones y nacionalismo, 24.

2I Tomás Pérez Vejo, "El problema de la nación en las independencias americanas: una propuesta teórica", Mexican Studies/ Estudios Mexicanos XXIV(2): 22I-244.

22 Véase Mónica Quijada, “Qué nación?”, 287-315. José Carlos Chiaramonte, Nación y Estado en Iberoamérica. El lenguaje político en tiempos de las independencias (Buenos Aires: Editorial Sudamericana, 2004).

Relaciones Estudios de Historia y Sociedad, vol. XL, núm 157, 2019 
23 José María Portillo Valdés, Revolución de nación, 326.

24 "Catecismo político arreglado a la Constitución de la Monarquía Española, para ilustración del pueblo, instrucción de la juventud y uso de las escuelas de primeras letras" (Madrid: Oficina de Collado, I8I2), 6.

25 Dorothy Tanck de Estrada, "Los catecismos políticos: de la Revolución francesa al México independiente", Antologías. Independencia y educación. Cultura cívica, educación indígena y literatura infantil (México: El Colegio de México, 2013), 254.

26 "Himno Patriótico", "Cádiz. Día ig de marzo de i8I4", Miscelánea.

27 "Primera proclama del ejército insurgente", Carlos Herrejón Peredo, Hidalgo, maestro, párroco e insurgente (México: Editorial Clío, 20I0), 237-238. El historiador aclara que fue redactada entre el i7 y el ig de septiembre de i8 Io.

28 "Comunicación de Hidalgo a Juan Antonio Riaño el 28 de septiembre de i8ı", tomado de Carlos Herrejón, Hidalgo, maestro, 246-247.

29 Luis Castillo Ledón, Hidalgo: la vida del héroe, 2 vols. (México: Cámara de Diputados, Fondo de Cultura Económica, 2003). Carlos Herrejón, Hidalgo, maestro.

30 José María Cos, "Plan de paz y guerra, i6 de marzo de i8I2", Documentos para la historia, 93IO3.

3i Ignacio López Rayón, "Primer proyecto constitucional para el México independiente. Elementos de la Constitución", Ibid., I05.

32 El artículo 34 estableció cuatro órdenes militares: Guadalupe, Águila, Hidalgo, Allende, Ibid., Io8.

33 Carlos Herrejón Peredo, Del sermón al discurso cívico. México, 1760-1834 (México: El Colegio de Michoacán, El Colegio de México, 2003), 319.

34 Mariana Terán, Por lealtad al rey, 330.

35 José María Morelos, "Sentimientos de la nación, i4 de septiembre de i8I2", Documentos para la historia, I28-I3I.

36 Ibid., I3I.

37 "Manifiesto de Morelos desde el cuartel universal de Tlacosautitlán, 2 de noviembre de I8I3". Tomado de Carlos Herrejón Peredo, Morelos, vol. I (Zamora: El Colegio de Michoacán, 2015), 436.

Relaciones Estudios de Historia y Sociedad, vol. XL, núm I57, 2019 
38 Carlos Herrejón Peredo, "Construcción del mito de Hidalgo", en El héroe entre el mito y la historia, ed. Federico Navarrete Linares y Guilhem Olivier, 235-249 (México: Centro de Estudios Mexicanos y Centroamericanos, 2000). Consultado en la versión electrónica, 20I3.

39 José Guridi y Alcocer, Diario de sesiones de las Cortes de Cádiz, 29 de diciembre de i8 Io.

40 Fragmento de la participación de Miguel Gordoa en la sesión del 20 de septiembre de i8ri. Tomado de Martín Escobedo, José Miguel Gordoa. El drama de la transición política (17771832) (México: Poder Legislativo del Estado de Zacatecas, Departamento de Estudios Históricos de la Arquidiócesis de Guadalajara, 2014), i35.

4I Francisco Martínez Marina, Teoría de las Cortes o grandes juntas nacionales de los reinos de León $y$ de Castilla (Madrid: Imprenta de Fermín Villalpando, I8I3), 59. La obra fue sancionada por las Cortes de Cádiz en i8ı2.

42 Mónica Quijada, Homogeneidad y nación. Con un estudio de caso: Argentina, siglos XIX y $X X$, Colección Tierra Nueva e Cielo Nuevo (Madrid: Consejo Superior de Investigaciones Científicas, 2000), 8.

43 Peter Wade, "Identidad racial y nacionalismo: una visión teórica de Latinoamérica", en Formaciones de indianidad: articulaciones raciales, mestizaje y nación en América Latina coord. Marisol de la Cadena, 388 (Popayán: Envión Editores).

44 Sesión del 7 de junio de I822. José Barragán y Barragán, Actas constitucionales mexicanas, tomo III, vol. II (México: Universidad Nacional Autónoma de México, I980), 29.

45 Sesión del ro de junio de i822, Actas constitucionales mexicanas, 40.

46 Colección de decretos y órdenes del Soberano Congreso Constituyente Mexicano, Iํㅡㄹ de marzo de i8z2.

47 Verónica Zárate ha analizado la polémica sobre qué días considerar como fiesta nacional, si el i6 o el 27 de septiembre. Sólo en i822 no se conmemoró el i6 de septiembre, "La conformación de un calendario festivo en México en el siglo XIX". Érika Pani y Alicia Salmerón, coords., Conceptualizar lo que se ve. François-Xavier Guerra, historiador. Homenaje (México: Instituto Mora, 2004), i88.

48 Sesión del i4 de junio de i822. Actas constitucionales mexicanas, 56. La propuesta fue de los diputados Joaquín Herrera, Esteva, Avilés y Robles. En esa misma sesión, Carlos María de Bustamante aclaró que, según una consulta del consejo de Estado a Felipe V, la práctica del besamanos era propia de la nación española "y de aquí infirió que el Congreso debe dictar un ceremonial propio de un pueblo libre".

49 Ibidem.

5o Ibid., 58.

Relaciones Estudios de Historia y Sociedad, vol. XL, núm 157, 2019 
5I Sesión del 22 de junio de I822, Ioo.

52 Ibid., 98.

53 Ibid., Iог.

54 Ibid., 102.

55 Ibid., I03.

56 Idem.

57 Ibid., I04.

58 Actas de la Diputación Provincial de la Nueva Galicia, Sesión III, Io de diciembre de i822, La diputación provincial de la Nueva Galicia, edición y sumario de Beatriz Rojas, estudio introductorio de Jaime Olveda (México: Instituto Mora, Universidad de Guadalajara, 2004), 258.

59 Carlos Herrejón, Del sermón al discurso cívico, 328-342.

6o Fausto Ramírez, "Hidalgo en su estudio: la ardua construcción de la imagen del Pater Patriae mexicano", en La construcción del héroe en España y México 1789-1847, ed. Manuel Chust y Víctor Mínguez, Igi (Valencia: Universitat de València, El Colegio de Michoacán, Universidad Veracruzana, Universidad Autónoma Metropolitana, 2003).

6r Carlos Herrejón, Del sermón al discurso cívico, 330-331.

62 Francisco García Diego. "Sermón que en la solemnísima función que hizo este Colegio de N.S de Guadalupe en acción de gracias por la feliz conclusión de la independencia del Imperio Mexicano dijo.... El día ir de noviembre de i82I", Guadalajara, Imprenta de Mariano Rodríguez, I822 (En la portada, una nota: "Este sabio sermón se ha dado a la luz a petición de los señores que componen el nuevo ayuntamiento constitucional del puesto de Guadalupe de Zacatecas, y dos vecinos de la misma ciudad, para la ilustración de sus caros hermanos y convencimiento de muchos preocupados).

63 Sesión del 2 de julio de i822, Actas constitucionales mexicanas, I44.

64 Francisco García Diego, "Sermón que en la solemnísima función”.

65 Sesión del 2 de julio de i822, Actas constitucionales mexicanas.

66 Verónica Zárate Toscano sostiene que encumbrar a ciertos personajes depende directamente de las "necesidades ideológicas" de los grupos en el poder, "Héroes y fiestas en el México decimonónico: la insistencia de Santa Anna". La construcción del héroe en España y México, I34. 
67 "Carta del Patriota Antiguo contra el presidente del ayuntamiento Manuel Rul, en la ciudad de Aguascalientes", AHEZ, fondo Ayuntamiento, serie Correo Político, 2i de septiembre de I 826 .

68 Denuncia del Sr. Murguía al español Joaquín de Bustamante, AHEZ, Fondo Ayuntamiento de Zacatecas, Serie Periódico Correo Político, 2i de julio de i826.

69 En este sentido, Juan Carlos Ruiz Guadalajara hace un detallado análisis del tránsito de la Congregación de Dolores del contexto novohispano, a su posición simbólica como cuna de la Patria. Véase Dolores antes de la Independencia: microhistoria del altar de la Patria(Zamora: El Colegio de Michoacán, El Colegio de San Luis, 2004), 23-62.

7o Citado por Eric Hobsbawn, Naciones y nacionalismo, 49.

7I Marta Terán, "Símbolos, emblemas", 207.

72 Bartolomé de Ita y Parra, "El círculo del amor", en Nueve sermones guadalupanos, 234.

73 William F. Taylor, "La virgen de Guadalupe en la Nueva España: una investigación sobre la historia social de la devoción mariana", en Entre el proceso global y el conocimiento local. Ensayos sobre el Estado, la sociedad y la cultura en el México del siglo XVIII, William F. Taylor, 4I6 (México: Universidad Autónoma Metropolitana, Conacyt, Miguel Ángel Porrúa, 200z).

74 Jorge Gómez y Ma. Eugenia Sánchez, La ideología mestizante, el guadalupanismo y sus representaciones sociales. Una revisión crítica de la identidad nacional (Puebla de los Ángeles: Universidad Iberoamericana, 20II), 20.

75 Ibid., 23.

76 José María Tornel, "Oración pronunciada por el coronel José María Tornel, diputado al Congreso de la Unión, vicepresidente de la Compañía Lancasteriana de México, socio de número de la Academia de Legislación y Economía de la misma ciudad, y corresponsal de la de Amigos del País de Zacatecas, en la plaza mayor de la capital de la federación, el día i6 de septiembre de i827, por acuerdo de la junta de ciudadanos que promovió la mayor solemnidad del aniversario de nuestra gloriosa independencia" (México: Imprenta del Águila, I827). Tomada de Ernesto de la Torre Villar, La conciencia nacional y su formación. Discursos cívico septembrinos, 1825-1871 (México: Universidad Nacional Autónoma de México, I988), 43.

77 Ibid., 45 .

78 Ibid., 44 .

79 Juan Francisco de Azcárate, "Elogio patriótico que pronuncio... el I6 de septiembre de i826 en la plaza mayor de México a presencia del presidente de la República Federal por nombramiento de la junta cívica, reunida en esta capital con el objeto de celebrar con la debida

Relaciones Estudios de Historia y Sociedad, vol. XL, núm 157, 2019

246 
solemnidad, el segundo aniversario del grito de independencia que dieron los primeros héroes de la nación el i6 de septiembre de i8 Io" (México: Imprenta del Águila, I826). Ibid., 35.

8o Francisco Manuel Sánchez de Tagle. "Arenga cívica que pronunció el i6 de septiembre de I83o, aniversario del glorioso grito de dolores, en la plaza mayor de México, el C. Francisco M. $\underline{\text { Sánchez de Tagle, elegido al efecto por la Junta Patriótica" (México: Imprenta del Águila, }}$ I830). Ibid., 76 .

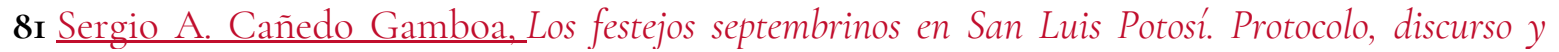
transformaciones, 1824-1847 (San Luis Potosí: El Colegio de San Luis, 200I), 42-46.

82 "Plan del gobierno americano entregado por Miguel Hidalgo a José María Morelos", zi de octubre de I8Io. Recuperado de: http://www.inehrm.gob.mx/work/models/inehrm/.pdf (Fecha de consulta: in agosto de 20I7).

83 Peter Wade, "Identidad racial y nacionalismo", 388.

84 "Carta de Un chismoso al periódico Correo Político para informar sobre las actividades del acto conmemorativo del I6 de septiembre en el mineral de Nieves", AHEZ, fondo Ayuntamiento de Zacatecas, serie Correo Político, 23 de septiembre de i827.

85 Noemí Goldman y Gabriel de Meglio, "Pueblo/pueblos", Noemí Goldman, ed., Lenguaje y revolución. Conceptos políticos clave en el Río de la Plata, 1780-1850 (Buenos Aires: Prometeo Libros, 2008), I37.

86 Mónica Quijada, Homogeneidad y nación, 20.

87 Noemí Goldman y Gabriel di Meglio, "Pueblo/pueblos", I37.

88 José María Tornel "Oración”, 4I.

89 J. M. Herrera, "Oración patriótica que pronunció en la plazuela principal de la Alameda de México... el 16 de septiembre de I829, aniversario del grito de Dolores" (México: Imprenta del Águila, I829). Ibid., 68.

\section{Idem.}

91 Diario de Sesiones de las Cortes Generales y Extraordinarias, 8 de abril de i8II. Edición digital (Alicante: Biblioteca virtual Miguel de Cervantes Saavedra, 2005).

92 Cfr. Tomás Pérez Vejo, "El problema de la nación en las independencias americanas: una propuesta teórica", Mexican Studies/Estudios Mexicanos 24(2): 22I-244.

93 Wenceslao Barquera, "Oración patriótica que pronunció ... el I6 de septiembre de I825" (México: Imprenta de la federación, r825). La conciencia nacional, 25.

Relaciones Estudios de Historia y Sociedad, vol. XL, núm I57, 2019 
94 José María Tornel, “Oración”, 45-46.

95 J. M. Herrera, "Oración patriótica", 67.

96 Juan Wenceslao Barquera, "Oración patriótica", 23.

\section{Mariana Terán Fuentes}

Obtuvo su doctorado en Historia por la Universidad Autónoma de Zacatecas en 20oo. Desde I993 es profesora investigadora de esa institución. A lo largo de ese tiempo ha cultivado como líneas de investigación el estudio del sermón novohispano, la guerra de insurgencia, el liberalismo gaditano y las formas de gobierno en México entre I824 y i 846 a través del análisis del caso del estado de Zacatecas. Sus publicaciones más recientes son Bosquejo de un inmenso cuadro. Liberalismo constitucional y formas de gobierno en Zacatecas, 1823-1846,(2015); Donde sopla el viento, más allá ... en La Blanquita (2016); La virtud de la administración pública. Tres ensayos sobre las Observaciones de Luis de la Rosa Oteiza (2017). Fue la creadora de la Cátedra Internacional de Federalismo "Francisco García Salinas".

\section{Mónica Pérez Navarro}

Obtuvo su doctorado en Humanidades con especialidad en Historia en la Universidad Autónoma Metropolitana. Ha cultivado como líneas de investigación la Historia Social y Cultural de Nueva España, Cultura Política, Afrodescendientes. Entre sus publicaciones destacan: "Cultura política en el Antiguo Régimen: distinción, políticas de segregación y conquista de espacios de interpelación en la Nueva España", publicado en la Revista del Colegio de San Luis; "Familia, matrimonio y convivencia doméstica entre negros y mulatos en los centros mineros novohispanos: el caso del Real de Minas de San Luis Potosí" en Historia y Familia. Vínculos parentales y metodología para el estudio de las familias en México, coord. Laura Elena Dávila Díaz; "Participación de negros y mulatos en los tumultos de 1767 en San Luis Potosí y Guanajuato", en Negros y morenos en Iberoamérica: adaptación y conflicto, coord. Juan Manuel de la Serna. 